Accepted refereed manuscript of:

Londoño-Roldan JC, Davies K \& Elms J (2017) Extending the Theory of Planned Behavior to examine the role of anticipated negative emotions on channel intention: The case of an embarrassing product, Journal of Retailing and Consumer Services, 36, pp. 8-20.

DOI: 10.1016/j.jretconser.2016.12.002

(C) 2016, Elsevier. Licensed under the Creative Commons AttributionNonCommercial-NoDerivatives 4.0 International http://creativecommons.org/licenses/by-nc-nd/4.0/ 


\title{
Extending the Theory of Planned Behavior to examine the role of anticipated negative emotions on channel intention: The case of an embarrassing product
}

\begin{abstract}
The Theory of Planned Behavior (TPB) is successful in predicting consumer intentions for a wide variety of products and behaviors. However, little is known about how effective the TPB is when the behavior under study is embarrassing. To this end, this paper extends the TPB to create a conceptual model to examine the role of anticipated negative emotions on channel intention. An empirical study was conducted whereby the model was tested using survey data on the purchase of Regaine (a hair loss product that is embarrassing to buy) in Boots (a well-known UK multichannel drugstore). The embarrassing nature of Regaine created differences in the importance that emotions played when consumers intend to purchase using face-to-face channels (such as the physical drugstore) as against multichannel options or the internet. The results were analyzed using partial least squares structural equation modelling (PLS-SEM). The effectiveness of the TPB was improved. The variance explained ( $\mathrm{R}^{2}$ to intention) was 0.44 percent for the total sample, 49 percent for the drugstore, 58.4 percent for the internet, and 42.5 percent for multichannel.
\end{abstract}

Key Words: Theory of Planned Behavior, Multichannel, Single-channel, Anticipated Negative Emotions, Embarrassing Products. 


\section{Introduction}

Multichannel retailing has changed the way consumers shop (Carlson, O’Cass, \& Ahrholdt, 2015). Although it is understood that multichannel shoppers spend more, the unanswered question remains why? (Anesbury et al. 2015). Moreover, little is known about what drives consumers to use single or multichannel options, with studies focusing on multichannel consumer behavior few and far between (Dholakia et al. 2010). Specifically, additional research has been called for to examine the interaction effects of rational and emotional drivers, the influence of environmental factors, and the use of multiple channels that influence shopper decisions (Pookulangara, Hawley, \& Xiao, 2011; Shankar et al. 2011). Accordingly, this paper contributes to the multichannel literature that studies the determinants of channel choice. It also indicates the best channel alternative for embarrassing products. This is important given the growing consumer preference for retailers who offer online channels (Pantano \& Viassone, 2015) and multichannel options (Dennis, Fenech, \& Merrilees, 2005).

The Theory of Planned Behavior (Ajzen, 1985), hereafter TPB, has been found as a useful lens to study consumer behavior (Heinhuis \& Vries, 2009) and, arguably, has the potential to predict multichannel shopper behavior and channel choice intentions. However, survey length has forced researchers to selected a limited number of the TPB constructs, or analyze only one channel at a time. This limitation has also been experienced by store format researchers (Nilsson et al. 2015). To the best of the authors' knowledge, the study reported in this paper is the first to overcome this limitation by analyzing channels under similar parameters.

One of the strengths of the TPB is its ability to capture the influence of social norms on intention. Arguably, this is needed in the retail area where social presence has a high influence on consumer behavior (Argo, Dahl, \& Manchanda, 2005) because it can ignite negative 
emotions, such as embarrassment. The TPB has been used repeatedly to study behaviors that could be embarrassing (Katsanis, 1994). For example, TPB studies of condom purchasing found that the channel influences the prediction of behavior, i.e., to obtain condoms from a clinic is different to buying them from a pharmacy (Fishbein \& Middlestadt, 2011).

Channels satisfy consumers in different ways, and these differences become clearer when a consumer is shopping for an embarrassing product: the advantages or disadvantages of a particular channel become more prominent. The embarrassing product used in this study to magnify these differences is a hair loss restorer, Regaine: a product in a category that has been previously classified as embarrassing (Lau-Gesk \& Drolet, 2008). Regaine is studied in the context of a recognized multichannel UK retailer: Boots. The embarrassing nature of the purchase situation under study supports the need to extend the TPB with a variable that accounts for the emotional charge created by the purchase. Anticipated Negative Emotions (ANE) are therefore included in this paper to respond to this challenge.

A particular channel, or combination of channels, could potentially offer the consumer a reduction of ANE, such as embarrassment, that create tension and inhibit a purchase. However, research has underscored that ANE is not adequately represented in TPB (e.g. Abraham \& Sheeran, 2003; Buunk et al. 1998; Parker et al. 1995; Richard et al. 1995; Sheeran \& Orbell, 1999), but could potentially explain more variance than other TPB constructs (Sandberg \& Conner, 2008; Ajzen \& Sheikh 2013).

To this end, the overall aim of this paper is to determine how effective the TPB is in predicting consumer behavior for an embarrassing product, in the context of a face-to-face channel (i.e. a drugstore) versus the internet and multichannel options. The research aim is answered using the TPB that allows for comparison between behavioral intention in terms of 
attitudes, subjective norm, and perceived behavioral control. In addition, the paper includes the role of ANE and answers to two research questions: (1) Are the direct measurements of the TPB able to explain intention in the case of shopping for an embarrassing product using a face-to-face versus the internet or multiple channel options? (2) What is the role of ANE in consumer behavior when shopping using face-to-face channels versus the internet or multichannel options?

In terms of organization, the remainder of this paper is structured as follows. The TPB is briefly reviewed, and the role of emotions and embarrassment in purchase decisions are considered. This is followed by the presentation of a conceptual model that extends the TPB by proposing the effects of ANE on channel intention. Thereafter, the methodology employed in this research is presented. The results are then described and discussed with reference to the extant literature, in particular the TPB variables and the introduced constructs. Finally, the main limitations of the findings are outlined, the managerial implications are described and discussed, and suggestions for further research are presented.

\section{Literature Review}

The Theory of Planned Behavior

The TPB has achieved a considerable reputation for predicting and explaining human behavior (Ajzen, 1985; Ajzen, 2002). Intentions are explained as a consequence of attitudes, subjective norm, and perceived behavioral control (Ajzen, 1985). The TPB has been used in a wide range of business and non-business related studies. A summary of the relevant literature that has used TPB in the context of channels and/or shopping behavior can be found in Table 1 . Other examples include: the prediction of organizational behavior, job performance, turnover, withdrawal behaviors, political behavior, voting participation and voting choice (Ajzen, 2011), 
as well as cardiovascular problems (Krones et al., 2010), motivations to exercise (Kwan \& Bryan, 2010), the use of educational technology (Lee \& Cerreto, 2010), downloading pirated software (Liao, Lin, \& Liu, 2010), extent of study (Liem \& Bernardo, 2010), participation in recycling programs (Nigbur, Lyons, \& Uzzell, 2010), undertaking cancer screening (Kim, Park, Hong, Lee, \& Kim, 2010), self-identity (Rise \& Hukkelberg, 2010), and the consumption of fruit (de Bruijn, 2010), alcohol (Glassman et al. 2010), and halal food (Alam \& Sayuti, 2011).

\section{Insert Table 1 about here}

The effectiveness of the TPB has been underscored by several meta-analyses (Godin \& Kok, 1996; Hausenblas, Carron, \& Mack, 1997; Van den Putte, 1991; Armitage \& Conner, 2001; Manning, 2009). Nevertheless, the TPB has numerous constraints and limitations that leave room for conceptual and operational improvement. For example, the TPB has been criticized because it overlooks the relative importance of norms, the nature of the situation, how behavior is being reported, and the control of internal or external factors (Armitage \& Conner, 2001; Hogg, 1996; Hogg et al. 1999; White et al. 1994). The current research addresses how the behavioral target context affects the relative importance of TPB variables. Another contextual related weakness in TPB is self-report bias (Armitage \& Conner, 2001). Hessing et al. (1988), for example, found inconsistencies between the self-reported intention to pay taxes and the official documentation presented. Although shopping for Regaine is not a dishonest behavior, it could be socially undesirable, affecting self-reports. When the nature of the situation is charged with emotional implications, accounting for emotions in the TPB model could improve its efficacy.

\section{Emotions}

One of the contributions of the present research is to provide more evidence for the significance of anticipated affect. Emotions are therefore included in this paper because the 
consumer will experience them when using any channel. The current research explores the role of anticipated negative emotions (ANE), like embarrassment, nervousness, or tension. From a TPB perspective, anticipated regret and anticipated affect are a part of attitudes (Ajzen \& Sheikh, 2013), and regret has been studied in shopping situations (Reynolds, Folse, \& Jones, 2006). However, anticipated affect is not satisfactorily embodied in the TPB (Abraham \& Sheeran, 2003; Buunk et al. 1998; Parker, Manstead, \& Stradling, 1995; Richard, Pligt, \& Vries, 1995; Sheeran \& Orbell, 1999). Reducing negative emotions, including embarrassment, can help managers to achieve the win-win solutions desired by shopper marketing (Shankar et al. 2011). In this study, the term anticipated is used to highlight the fact that the focus is on the feelings generated about the possible consequences of the behavior.

ANE are therefore defined as the negative feelings that might arise after a certain action or inaction (Pligt, 1998). ANE are measured using a combination of negative emotions, such as regret, sadness, shame, embarrassment, etc., depending on the context studied (see, Conner, 2006; Sandberg, 2008). ANE are distinct from attitudes, and focus on the feelings that individuals anticipate if, or after, they perform a bad behavior (Abraham \& Sheeran, 2004; Ajzen \& Fishbein, 2005; van der Pligt, \& de Vries, 1996).

\section{Embarrassment}

Embarrassment occurs when individuals experience threats to their public self (Miller \& Leary, 1992). Embarrassment can also be experienced in private, when individuals imagine what others might think of them (Sabini, Garvey, \& Hall, 2001). Embarrassment is very powerful in regulating social behavior; this includes shopping. Embarrassing products are those that people need and seek out, but do not discuss openly, and include personal hygiene products, birth control, or condoms (Katsanis, 1994). It has been suggested that the internet creates an emotional 
relief from embarrassment (Wolfinbarger \& Gilly, 2000). Embarrassment has been studied using the TPB in the case of counterfeit products (Penz \& Stottinger, 2005), breast-feeding (Khoury et al. 2005), de-shopping (King \& Dennis, 2003), music piracy (Morton \& Koufteros, 2008), mammography (Steele \& Porche, 2005), and coupons (Bagozzi, Baumgartner, \& Yi, 1992).

There is also more research needed to understand men's feelings, insecurities, and desires (Crossley, 2004). Today, many men feel less embarrassed about shopping for beauty products (Datta \& Paramesh, 2010). Retailers and manufacturers are aware of men’s apprehension about being labeled feminine or 'gay', and train salespeople to provide an appropriate service to hesitant consumers of grooming products (Zayer \& Neier, 2011). Grooming products are used more predominantly by men who live in urban populations, compared with their rural counterparts (Nair, 2007). Consequently, the sample used in the current research was selected from an urban population and contributes to previous research that has studied male shopping behavior (Otnes \& McGrath, 2001).

\section{Research Hypotheses}

Attitudes develop from beliefs about objects or behaviors (Fishbein \& Ajzen, 1975). Attitudes can be positive or negative. In the case of behaviors, attitudes give a positive or negative expectation of a particular outcome. The TPB underscores that there is a positive correlation between attitudes and intention (Ajzen, 1985).

\section{H1. Attitudes have a positive impact on Intention}

Subjective Norm (SN) refers to the pressure that society exerts on an individual (Ajzen \& Driver, 1992). SN is composed of the beliefs that the individual has about what society's norms are. SN also depends on what is perceived to be the individual's behavior by important referents, 
including family, neighbors, and/or co-workers. Another important component of SN is the motivation that the individual has to comply or act in accordance with others' opinions about what their behavior should be (Ajzen \& Fishbein, 1980).

\section{H2. Subjective Norm has a positive impact on Intention}

Perceived behavioral control (PBC) originates from Atkinson's Theory of Achievement Motivation (Atkinson 1964). Atkinson (1964) introduced the concept of expectancy of success, which refers to the probability that an individual has of succeeding. Therefore, individuals are motivated if they feel that there is a good probability that they will succeed, or that they can control their success. This sense of control of success evolved into a sense of control in behavior. PBC reflects the perception of how easy or how difficult it is for a person to execute certain behavior. PBC considers both internal and external factors. This contrasts with the concept of locus of control, in which an individual expects that outcomes depend on their behavior no matter the context (Rotter, 1966). The PBC concept is very similar to Perceived Self Efficacy (PSE) (Ajzen 2002). Furthermore, Bandura et al. $(1977 ; 1980)$ found that behavior is influenced by the confidence that a person has in their ability to perform a certain task or not.

\section{H3. Perceived Behavioral Control has a positive impact on Intention}

Recent studies have found that emotions (Moons \& De Pelsmacker, 2012), in particular ANE, are a better predictor of intentions compared to other TPB variables (Wang, 2011; Sandberg \& Conner, 2008). This includes attitudes (Moons \& De Pelsmacker, 2012; Wang, 2013) in different contexts, for example the intention to perform physical exercise (Abraham \& Sheeran, 2004; Perugini \& Bagozzi, 2001). Performing a shopping task in the presence of others can ignite negative emotions, such as embarrassment. The TPB has been repeatedly used to study 
behaviors that could be embarrassing, including buying condoms (Katsanis, 1994), or downloading music illegally (Morton, 2008). TPB condom studies found that the channel influences the prediction of behavior.

A meta-analysis study found that anticipated affect accounts for an additional 7 percent of the variance in intentions (Ajzen \& Sheikh, 2013). Keer, Van Den Putte and Neijens (2012) demonstrated that affect partially mediated the influence of attitude and perceived behavioral control on intention. Table 2 presents a list of studies that confirm the relationship between emotions and intentions. The large number of studies found supports the creation of a link between these two constructs.

H4. Anticipated Negative Emotions (ANE) have a negative impact on Intention

\section{Insert Table 2 about here}

\section{Methodology}

Survey design. This research followed a causal, cross-sectional, non-experimental, survey design. It used a self-administered data collection instrument. The survey instrument facilitated the quantitative measurement of responses in a simple paper and pen format. The behavior was defined in terms of target, action, context, and time (TACT) elements (Ajzen, 2011). In this way, the survey instrument was designed to meet the principles of specificity, generality, and compatibility (Ajzen, 2002), and was defined in terms of the same elements for $\mathrm{AB}, \mathrm{SN}$, and PBC. Consequently, the behavior was defined as 'Shopping for Regaine in a Boots Drugstore' for the first context; 'Shopping for Regaine from a Boots Website' for the second context; and, 'Shopping for Regaine in Boots using multichannel' for the third context. A list of items used in the survey, along with their sources, can be found in Table 3. 


\section{Insert Table 3 about here}

Not all consumers understand what multichannel is, therefore at the beginning of the survey a section highlighted in bold and capital letters called for the attention of the respondent: IMPORTANT DEFINITION: By Multichannel we mean using a combination of channels (store+internet or store+mobile).

The TPB does not provide researchers with a standardized scale to measure the main constructs, instead it suggests, as in this study, that an elicitation study is performed. Elicitation procedures are recommended when using the TPB to establish the cognitive foundation of the population's salient beliefs (Conner \& Sparks, 1996). Following these recommendations, the elicitation study involved interviewing a small number of respondents from the sample described below, and the beliefs obtained were used to inform the survey design, as the main way in which to measure the relationships between the theory constructs. In all, 32 men participated in the elicitation study, 10-11 for each Shopping Environment (SE). The particularities of the context provided by each channel made the beliefs elicited different. The elicitation study also helped to validate the constructs, and made them fit with the specificities of the behavior as well as the population of interest.

Sample. The research population was defined as men aged between 18 to 65 years who lived in the UK. The research sample was selected from a group of men aged between 18 to 65 years who lived in or around two urban cities with a population of more than 20,000 inhabitants. There was no sampling frame for this study; there is no list of men who use Regaine. Any man is susceptible to lose his hair, therefore, all men were considered as a potential Regaine user. As noted above, to gain more insights into single and multichannel, three SEs were compared. The 
sample was therefore classified into three groups: drugstore, internet, and multichannel. This triplicated the efforts in terms of sample size, since each group required an individual sample. The recommended sample size was calculated using the software G-Power 3.1 (Faul et al. 2007). The software output suggested a sample of 61 respondents for each of the three groups (183 in total). This number corresponded to an effect size of 0.6, $\alpha$ error of 0.05 and Power of 0.95 . Financial and time constraints also limited the number of surveys that could be collected. Additionally, the number of surveys was reduced after the respondents with very low intention were removed from the sample. In all, the sample consisted of 63 respondents from the drugstore, 62 from the internet, and 61 from multichannel (thus, 186 were used for the total sample calculations). This sample also meets the requirements of PLS studies which demand a sample is either: (1) ten times the scale with the largest number of formative indicators (reflective indicators can be ignored), or (2) ten times the largest number of structural paths directed at a particular construct (Chin, 2010b). In this study, this would therefore suggest a sample size of 60 or more cases in each of the three groups, as there are a maximum of six structural paths directed at intention.

Data collection. The data was collected in two barbershops over a three month period. This avoided the bias of collecting information close to one of the evaluated SEs, such as the internet or the drugstore. During the data collection period, the researcher remained on site for eight hours per day to access the men waiting to have their haircut. The data was collected from Mondays to Saturdays. Data collection on Saturdays was important because this was the busiest day for the barbers and this created a waiting queue (thus providing a captive audience). A small percentage of respondents returned to the barbershop after three or four weeks, however, these men were not asked to repeat the survey. 
Assessing common method variance (CMV) and non-response bias. Cross-sectional studies, such as reported in this paper, can suffer from CMV (Lindell \& Whitney, 2001), particularly in TPB research whereas respondents report both their attitudes and their intentions. To counter CMV, this study followed the control mechanisms developed by Podsakoff et al., (2003) and Liang et al., (2007). The subsequent results showed that method factor loadings were insignificant, and the indicators' variances were greater than their method variances; thus it can be concluded that common method bias is unlikely to be a serious concern in this study. Moreover, to reduce any likely impact of non-response bias, as noted above, the data was collected in barbershops when the respondents were waiting in line to get a haircut. This situation decreased the chances of non-responses to the survey. Therefore, the number of rejects was minimal. In this study, $10 \%$ of the respondents at most were not able to read the questionnaire (as they did not have access to their reading glasses). The barbershops also

provided an ideal environment in which to discuss hair related issues and thus encouraged participation with the survey.

\section{Results}

Table 4 presents a summary of the main descriptive statistics for each of the evaluated constructs in each SE. The constructs used in this research had a varied number of items. The constructs' mean ranged from 3.37 to 4.33 in the drugstore, from 2.17 to 5.07 on the internet, and from 2.59 to 4.73 in multichannel.

\section{Insert Table 4 about here}

Most respondents were not very embarrassed/nervous/tense about shopping for Regaine, however, the ANE's mean was higher in the drugstore (3.37) compared to the internet (2.17) and 
multichannel (2.59). The highest mean for a construct was PBC, which ranged from 4.2 to 4.79. This response could imply that consumers did not find control issues while shopping for Regaine. A graphic representation of the total sample is presented in Figure 1. The drugstore conceptual model is presented in Figure 2, the internet conceptual model is presented in Figure 3, and the multichannel conceptual model is presented in Figure 4. These figures illustrate the inner and outer model relationships. Each figure represents the indicators and latent variables that were ultimately used in this research.

\section{Insert Figure 1, 2, 3 and 4 about here}

Measurement Model Results: Loadings were evaluated in order to assess the outer model. Standardized indicator loadings should be greater than or equal to 0.7. In exploratory studies, loadings of 0.40 are acceptable (Hulland, 1999). Indicators AT1,4,5,6,7,8, SN 3 and PBC1 were dropped from each sample because they did not achieve a 0.7 loading or were not relevant in all SEs.

Table 5 presents the loadings and quality indicators for the complete sample. For the complete sample, the loadings obtained by the model are all above the 0.7 level suggested. Composite reliability ranged from 0.73 to 0.94 , and was above the 0.7 level for all constructs. The above data indicates that constructs were well built. For the drugstore, the loadings obtained by the model are all above the 0.7 level suggested, with the exception of AT9 and SN2 that had a 0.67 loading. Composite reliability ranged from 0.76 to 0.98 , and was above the 0.7 level for all constructs. The above data indicates that constructs were well built. For the internet, the CR ranged from 0.73 to 0.91 , above the 0.7 level for all items. The internet SE presented good quality loadings, above the 0.7 level with the exception of SN1 (0.69) and SN2 (0.62). For 
multichannel, the loadings were all above the 0.7 level suggested, with the exception of SN2 (0.48) SN4 (0.69) and PBC3 (0.38). The composite reliability ranged from 0.62 to 0.87 and was above or equal to the 0.7 level with the exception of PBC (0.62).

\section{Insert Table 5 about here}

Structural Model Results: At this point, the suitability of the outer measures has been established. It is now necessary to provide evidence of the quality of the inner model. This research proposed a model that contained four independent variables and one dependent variable. The PLS algorithm was able to calculate an estimate $\mathrm{R}^{2}$ for the dependent variable. The strength of the theoretical model was established by two factors: the $\mathrm{R}^{2}$, and the significance of the structural paths. The $\mathrm{R}^{2}$ was calculated using the PLS algorithm with 300 iterations. The significances were calculated using the bootstrap approach with 5000 re-samples. Chin (1998) and Falk and Miller (1992) suggest that the variance explained $\left(\mathrm{R}^{2}\right)$ should be greater than 0.1. All of the $\mathrm{R}^{2} \mathrm{~s}$ for the three channels achieved high variance explained scores. All were above the 0.1 recommended levels. The $\mathrm{R}^{2}$ statistics are shown in Table 6 .

\section{Insert Table 6 about here}

Discriminant validity was assessed using the Fornell Larker criterion (1981). All constructs of each of the three SEs analyzed were strongly correlated with their own measures, and more than with any of the other constructs. The results suggested that the research achieved good discriminant validity, as illustrated in Table 7.

\section{Insert Table 7 about here}


Discriminant validity was also evaluated at the item level. The procedure used to evaluate discriminant validity at the item level was to compare the loadings of the item with its own construct versus its cross-loadings with other variables. In the total sample and each of the evaluated SEs, all the items loaded strongly, as can be seen from Tables 8-11.

\section{Insert Table 8, 9, 10 and 11 about here}

The significance of the hypothesis tested was evaluated using the bootstrap approach, which helped to estimate the precision of the PLS estimates (Efron, 1981; Henseler, Ringle, \& Sinkovics, 2009; Chin, 2010a). N samples are created in order to obtain $\mathrm{N}$ estimates for each parameter in the PLS model. 5000 re-samples were used in the PLS bootstrap estimates, corresponding to the recommendation made by Hair et al. (2011). In any case, the number of bootstrap samples must be greater than the number of valid observations (more than 61 in this research).

Analysis of Significances and Coefficients. Table 12 presents the coefficients and significances of the evaluated paths.

\section{Insert Table 12 about here}

Cross Channel Findings: Two of the three TPB original variables were significant in the three SEs: ATT $\rightarrow$ Intention. ATT had a high and positive significance on intention across the three SEs and in the total sample. ATT had coefficients of 0.43 in the drugstore, 0.43 on the internet, and 0.39 in multichannel. ATT had t-statistics of 5.209 in the drugstore, 3.099 on the internet, and 2.66 in multichannel. However, PBC was not significant in any of the three evaluated SEs. ANE had a significant impact on the intention to shop in the drugstore $(-0.298$ 
Coef. and 3.486*** t-statistic), but not in either the internet (0.033 Coef. and 0.314 t-statistic), or multichannel (-0.053 Coef. and 0.35 t-statistic). The greater the ANE the less likely men would want to shop for Regaine in the drugstore.

The coefficients of ATT and SN were positive when significant relationships were found.

\section{Insert Table 13 about here}

Effect Size: To evaluate the model, the effect size was also subject to examination. The Software Smart PLS 3.2.6. is able to calculate effect size f automatically. The analysis of the effect size is presented in the discussion section and is based on the results shown in Table 14 .

\section{Insert Table 14 about here}

MGA Analysis Findings: MGA measures the difference in the path coefficients of two groups of data sets and their significance. In this study, as presented in Table 15, there were no significant differences in the evaluated groups, with the exception of ANE on intention. In this case, the drugstore was significantly different. This difference shows that while ANE are important in the drugstore, they are not relevant in the internet or multi-channel context.

\section{Insert Table 15 about here}

\section{Discussion}

The results of this research agrees partially with the TPB theory because it showed that men's intention to shop for an embarrassing product using a single or multiple channels was positively associated with their attitude and subjective norms in both single (drugstore and internet) and multichannel contexts. This finding is in line with other studies focusing on the 
internet as a shopping channel, which have established a relevant connection between attitudes and intention (Lin, 2008; Shim \& Drake, 1990; Shim et al. 2001).

SN showed a medium to large effect and predictive relevance on intention in the three SEs. SN also achieved significance in all three of the paths leading to intention. Consequently, SN constituted itself as a relevant construct to explain intention in all the SEs. This finding is consistent with TPB studies that have shown the relevance of SN. SN is a concept that augments its importance when the context of the behavior is embarrassing, like the intention of students to buy condoms (Lavoie \& Godin, 1991). This paper demonstrates that subjective norm was also important for the multichannel SE. Multichannel has been an area where SN studies have been limited. The result supported the validity of SN as a predictor of intention even under different channels/contexts and the importance of the social environment on the shopping experience (Verhoef et al. 2009). This confirms the importance of social relationships and privacy on the channel selected (Albesa, 2007).

PBC was found irrelevant to predict intentions for all of the evaluated SEs. This result is surprising, given the amount of literature that supports the TPB and the importance of PBC. However, some studies that have tested emotions and TPB variables simultaneously have found that PBC becomes non significant (Schuster, 2013). Separate analysis shows that the PBC significance and loadings decrease as other factors are included in the model.

ANE negatively affected (decreased) intention to shop in the drugstore and were not relevant on the internet. It is interesting how multichannel was able to minimize the importance of negative emotions. Embarrassment theories confirmed that face-to-face interaction generated negative emotions (Grace, 2007). This result confirms the complementarities between channels (van Birgelen, de Jong, \& de Ruyter, 2006) that should be further considered by managers. ANE 
were able to explain intention for the drugstore. This finding is consistent with previous research that provided evidence for the link between anticipated negative emotions and intention (Bagozzi \& Pieters, 1998) for situations in which social exposure is latent.

ANE were important for the single channels but not for the multichannel context. This finding further emphasizes the advantages for retailers of using a multichannel strategy, and implies that multichannel is useful to decrease the importance that ANE have in the purchase of embarrassing products.

\section{Limitations, Managerial Implications, and Suggestions for Further Research}

\section{Limitations}

The potential TPB questionnaire length was a limitation for this paper as the three different SEs needed to be compared. To avoid this problem, this paper performed three separate questionnaires, one for each SE; however, this also had implications as each questionnaire required a separate sample. In addition, the paper was limited to the study of only one product category and the shopping experience was evaluated holistically, rather than being de-composed into shopping phases i.e., search and purchase. Financial and time constraints also limited the number of surveys that could be collected.

However, the use of PLS permitted an adequate statistical analysis of the variables. The characteristics of the data and the model were considered in the selection of the sample size. One of the disadvantages in the sample was the low penetration rate of Regaine users found in it. The lack of data on behavior created a limitation in terms of corroborating the connection between intention and behavior. Given the inability to establish a connection with behavior, this research focused its efforts on intention. 
The use of a cross-sectional study relies on analyzing the data from a single point in time. Over long periods, the consumer can change their perception of shopping for Regaine using the drugstore or the internet. These changes can occur because of the development of better in-store customer service and/or technological advances impacting the desirability of internet or multichannel options, thus affecting consumers’ attitudes, subjective norms, and/or perceptions of control over the shopping process. With a cross-sectional study design, these changes would not be perceived. The cross-sectional nature of this paper also had the limitation of reducing common method variance bias and enhancing causal inferences (Bosnjak, Galesic, \& Tuten, 2007). However, the cross-sectional design was adequate to answer the research aims of this study, as it corresponds to the positivist philosophy followed in the paper. The cross-sectional design permitted the researchers to compare channels and a large number of variables at one point in time.

The measurement of emotions is a difficult task, particularly as they can be context specific. Knowledge about the role of emotions in the marketing field is relatively new (Agnoli, Begalli, \& Codurri, 2009). This research overcame the limitation of emotion measurement using perceived emotions instead of felt emotions. Whilst the list used to evaluate emotions did not include all possible emotions, it was developed especially to consider emotions related to consumption (Richins, 1997).

The TPB requires that the behavior to be evaluated be 'reasoned'. This creates a limitation for the use of this framework in categories associated with low involvement. To use the TPB model, the researcher is required to use a well-known brand and retailer. This limits the applicability of future studies since many of the brands/retailers do not have large market share or brand awareness. Regaine was selected because it is a product where shopping decisions can 
have a high level of involvement (Basara, 1994; Ruby \& Montagne, 1992). People do not shop immediately for a high involvement product after watching its advertising; people plan and consider the purchase before starting their shopping trip. This product characteristic was valuable for the current research because it resonates with the requirements of the TPB: that the consumer reasons about their behavior. The brand selected for this paper was on the mind of many consumers.

\section{Managerial Implications}

This research emphasizes the need for organizations to better understand the potential advantages and disadvantages of particular channels for different consumer groups. Specifically, manufacturers and retailers should recognize the particularities of embarrassing products, as well as understand how negative emotions could generate approach or avoidance behaviors towards certain SEs. The findings of this research demonstrate that the optimal channel for the retailing of embarrassing products is multichannel, as the inherent characteristics of multichannel strongly reduces, or eliminates, the negative emotions created by embarrassment. Multichannel options are recommended for retailers of embarrassing products, as a combination of routes to market reduces the effects of embarrassing emotions as well as rewards customers with choice and flexibility. Manufacturers and retailers should communicate to consumers at different touchpoints (pre-purchase, purchase, and post-purchase) that the internet as well as multichannel options are the best alternatives to purchase particular embarrassing products.

Consequently bricks and mortar retailers that sell embarrassing products should consider investing in an online presence. Furthermore, retailer managers should attempt to reduce the role of negative emotions in an at-store purchase situation. This could be achieved by reinventing a store's layout, and re-aligning customer service in ways that minimize face-to-face contact 
between consumers and staff. Moreover retailers and manufacturers should collaborate to provide training to their customer service staff. Representatives of an organization should be able to answer any questions with confidence, without making consumers feel uncomfortable or embarrassed.

Furthermore, retailers could also develop online mechanisms that allow the customer to indicate that they would prefer to receive the purchased item 'in secret'. For example, retailers, such as ASDA/Walmart, are developing lockers where customers can pick up products ordered online. Such lockers could be opened with a code given to the consumer online. This eliminates any source of human interaction in the collection of the purchase, hence embarrassment. Orders could be picked up at different locations such as business parks, universities, train stations, and park-and-ride schemes (Lawson, 2013). This improvement in multichannel delivery increases the competitiveness of this channel alternative, and increases the perception that multichannel is close and easy to use which, as ascertained in this study, is one of the main strengths of physical stores.

Future Research

Researchers should continue to use the TPB to study multichannel retailing in the future. The study reported in this paper used self-report data to evaluate intention. Future studies may be able to use new technologies to eliminate the disadvantages of self-reporting, such as measuring the amount of time spent by the consumer in each channel. In addition, the measurement of 'other items' purchased alongside a product such as Regaine could help to provide a wider view of what is implied when the consumer is thinking about 'shopping for Regaine' and if there are differences while shopping using single channels or multichannel options. This could become even more important in the future as the number of channels available to consumers increases. 
The limitations in survey length narrowed the number of channels tested to the drugstore, the internet and by multichannel and excluded, for example, the use of catalogues and mobile/SMART phones. These channels should be included in future studies if mechanisms can be found to overcome the problems of data collection. Future researchers should also examine the impact of variables like the frequency of visits to the retailer and its location.

Replicating the model presented in this paper with a larger sample size could improve the study. Firstly, it would allow the researcher to use some of the new PLS tools to uncover customers' heterogeneity, such as FIMIX response-based segmentation. Secondly, a larger sample could have allowed the use of CBSEM. In this way, the results could have benefited from better parameter accuracy and the possibility to calculate the goodness of fit indicators that were missing from this study. Thirdly, a larger sample size would help to decrease the standard error and detect smaller effect sizes.

More research is needed to determine if purchasing online is embarrassing at all. The internet eliminated to a great extent the ANE associated with shopping for Regaine. A company that is known for promoting consumer privacy and avoiding consumers' embarrassment on one channel can influence its image on other channel. Research has shown that a strong prior offline brand image can influence online image (Kwon \& Lennon, 2009).

But other uses of the internet, such as social networking sites, may put the consumer under the constant pressure of subjective norms. Although the people who influence could be the same as those identified in this paper, for example their partner or spouse, social media exposes the consumer to more people commenting on their personal appearance. This occurs because consumers post pictures of themselves, which are seen by old school friends that they have not seen for a long time. The first thing that others notice is changes in the physical appearance such 
as hair loss. An analysis of social sites could illustrate the dynamics of social norms and hair related issues. Future research could include the effect that social networking sites like Facebook have on consumers' multichannel intentions (Jang, Chang, \& Chen, 2013).

\section{Conclusions}

This paper has successfully answered the research aims outlined in the introduction. The study reported in this paper illustrated the effects of emotional drivers on consumers' intention to use single or multiple channels to purchase an embarrassing product. The findings underscore that ANE have a more significant influence in the physical channel of the drugstore. The extended TPB model was more effective in predicting consumer behavior in face-to-face channels (the drugstore) compared to the internet or multichannel options. The most effective variables to explain purchase intention in both single and multichannel was Attitude and Subjective Norm. PBC was not effective on any channel. The TPB effectiveness was improved in the case of shopping for embarrassing products. ANE were particularly useful to explain the

drugstore SE. The TPB original variables were partially effective; multichannel options and the internet served to eliminate the influence of ANE. Methodological innovations introduced in this study highlighted the role that emotions have on intention. The changes in the importance of ANE in this study provided valuable insights into the benefits and challenges of a multichannel retail environment for retailers of embarrassing products. Moreover, in this context, the findings would also suggest that multichannel shoppers spend more because their behavior is not impacted by the negative emotions generated by shopping in a physical store. 


\section{References}

Abraham, C., \& Sheeran, P. (2003). Acting on intentions: The role of anticipated regret. British Journal of Social Psychology, 42(4), 495.

Abraham, C., \& Sheeran, P. (2004). Deciding to exercise: The role of anticipated regret. British journal of health psychology, 9(2), 269-278.

Agnoli, L., Begalli, D., \& Codurri, S. (2009). Consumer Emotions and Preferences: an empirical analysis in two Italian denomination of origin wines. Paper presented at the OEOEnometrie XVI - Namur - 2009.

Ajzen, I. (1985). From intentions to actions: A theory of planned behavior. In Springer (Ed.), Series in Social Psychology (pp. 11).

Ajzen, I. (2002). Perceived Behavioral Control, Self-Efficacy, Locus of Control, and the Theory of Planned Behavior. Journal of Applied Social Psychology, 32, 1.

Ajzen, I. (2011). The theory of planned behaviour: Reactions and reflections. Psychology \& Health, 26(9), 1113. doi:http://dx.doi.org/10.1080/08870446.2011.613995

Ajzen, I., \& Fishbein, M. (2005). The influence of attitudes on behavior. The handbook of attitudes, 173, 221.

Ajzen, I., \& Sheikh, S. (2013). Action versus inaction: anticipated affect in the theory of planned behavior. Journal of Applied Social Psychology, 43(1), 155.

Alam, S. S., \& Sayuti, N. M. (2011). Applying the Theory of Planned Behavior (TPB) in halal food purchasing. International Journal of Commerce and Management, 21(1), 8.

Albesa, J. G. (2007). Interaction channel choice in a multichannel environment, an empirical study. International journal of bank marketing, 25(7), 490.

Anesbury, Z., Nenycz-Thiel, M., Dawes, J., \& Kennedy, R. (2015). How do shoppers behave online? An observational study of online grocery shopping. Journal of Consumer Behaviour.

Argo, J. J., Dahl, D. W., \& Manchanda, R. V. (2005). The influence of a mere social presence in a retail context. Journal of Consumer Research, 32(2), 207.

Armitage, C. J., \& Conner, M. (2001). Eficacy of the theory of planned behaviour: A metaanalytic review. British Journal of Social Psychology, 40, 471.

Babin, B. J., \& Babin, L. A. (1996). Effects of moral cognitions and consumer emotions on shoplifting intentions. Psychology \& Marketing, 13(8), 785.

Bagozzi, R. P., Baumgartner, H., \& Yi, Y. (1992). Appraisal processes in the enactment of intentions to use coupons. Psychology \& Marketing, 9(6), 469.

Bagozzi, R. P., Gopinath, M., \& Nyer, P. U. (1999). The role of emotions in marketing. Journal of the Academy of Marketing Science, 27(2), 184.

Bagozzi, R. P., \& Pieters, R. (1998). Goal-directed emotions. Cognition \& Emotion, $12(1), 1$.

Baker, R. K., \& White, K. M. (2010). Predicting adolescents' use of social networking sites from an extended theory of planned behaviour perspective. Computers in Human Behavior, 26(6), 1591. doi:10.1016/j.chb.2010.06.006

Basara, L. R. (1994). Practical considerations when evaluating direct-to-consumer advertising as a marketing strategy for prescription medications. Drug information journal, 28(2), 461.

Bigné, J. E., Mattila, A. S., \& Andreu, L. (2008). The impact of experiential consumption cognitions and emotions on behavioral intentions. Journal of Services Marketing, 22(4), 303. 
Bosnjak, M., Galesic, M., \& Tuten, T. (2007). Personality determinants of online shopping: Explaining online purchase intentions using a hierarchical approach. Journal of Business Research, 60(6), 597.

Bozinoff, L., \& Ghingold, M. (1983). Evaluating guilt arousing marketing communications. Journal of Business Research, 11(2), 243.

Brown, S. P., Cron, W. L., \& Slocum Jr, J. W. (1997). Effects of goal-directed emotions on salesperson volitions, behavior, and performance: A longitudinal study. The Journal of Marketing, 39.

Buunk, B. P., Bakker, A. B., Siero, F. W., Eijinden, R. J. J. M., \& Yzer, M. C. (1998). Predictors of AIDS-preventive behavioral intentions among adult heterosexuals at risk for HIVinfection: Extending current models and measures. AIDS Education and Prevention, 10(2), 149.

Carlson, J., O’Cass, A., \& Ahrholdt, D. (2015). Assessing customers' perceived value of the online channel of multichannel retailers: A two country examination. Journal of Retailing and Consumer Services, 27, 90-102.

Carrera, P., Caballero, A., \& Munoz, D. (2012). Future-oriented emotions in the prediction of binge-drinking intention and expectation: the role of anticipated and anticipatory emotions. Scandinavian Journal of Psychology, 53(3), 273.

Chang, L.-C. (2010). The effects of moral emotions and justifications on visitors' intention to pick flowers in a forest recreation area in Taiwan. Journal of Sustainable Tourism, 18(1), 137.

Chapman, G. B., \& Coups, E. J. (2006). Emotions and preventive health behavior: worry, regret, and influenza vaccination. Health Psychology-Hillsdale Then Washington Dc-, 25(1), 82.

Chin, W. W. (1998). The partial least squares approach for structural equation modeling. In G. A. Marcoulides (Ed.), Modern methods for business research. Methodology for business and management. (Seventh ed., pp. 295). Nj: Lawrence Erlbaum Associates.

Chin, W. W. (2010a). Bootstrap cross-validation indices for PLS path model assessment. In V. Esposito Vinzi, W. W. Chin, J. Henseler, \& H. Wang (Eds.), Handbook of partial least squares (First ed., pp. 83). Berlin: Springer.

Chin, W. W. (2010b). How to write up and report PLS analyses Handbook of Partial Least Squares (First ed., pp. 655). Berlin: Springer.

Cohen, J. (1988). Statistical power analysis for the behavioral sciences (Second ed.). Hillsdale, New Jersey. U.S.A.: Lawrence Erlbaum Associates Inc.

Conner, M., Sandberg, T., McMillan, B., \& Higgins, A. (2006). Role of anticipated regret, intentions and intention stability in adolescent smoking initiation. British Journal of Health Psychology, 11(1), 85-101.

Crossley, L. (2004). Bridging the emotional gap. In D. McDonagh, P. Hekkert, \& J. Erp (Eds.), Design and Emotion (London: Taylor \& Francis ed., pp. 37): CRC Press.

Darden, W. R., \& Dorsch, M. J. (1990). An action strategy approach to examining shopping behavior. Journal of Business Research, 21(3), 289. doi:Doi: 10.1016/01482963(90)90034-b

Datta, H. S., \& Paramesh, R. (2010). Trends in aging and skin care: Ayurvedic concepts. Journal of Ayurveda and integrative medicine, 1(2), 110.

de Bruijn, G. J. (2010). Understanding college students' fruit consumption. Integrating habit strength in the theory of planned behaviour. Appetite(54(1)), 16. 
Dennis, C., Fenech, T., \& Merrilees, B. (2005). Sale the 7 Cs: teaching/training aid for the (e-) retail mix. International Journal of Retail \& Distribution Management, 33(3), 179.

Dholakia, U. M., Kahn, B. E., Reeves, R., Rindfleisch, A., Stewart, D., \& Taylor, E. (2010). Consumer Behavior in a Multichannel, Multimedia Retailing Environment. Journal of Interactive Marketing, 24(2), 86. doi:DOI: 10.1016/j.intmar.2010.02.005

Efron, B. (1981). Nonparametric estimates of standard error: the jackknife, the bootstrap and other methods. Biometrika, 68(3), 589.

Falk, R. F., \& Miller, N. B. (1992). A primer for soft modeling: University of Akron Press.

Fishbein, M., \& Middlestadt, S. E. (2011). Using Behavioral Theory to Transform Consumers and Their Environments to Prevent the Spread of Sexually Transmitted Infections. In Taylor \& G. Francis (Eds.), Transformative Consumer Research for personal and collective wellbeing (First Edition ed., pp. 391): Routledge Academic.

Fornell, C., \& Larcker, D. F. (1981). Structural equation models with unobservable variables and measurement error: Algebra and statistics. Journal of Marketing Research, 18(3), 382.

Fröhlich, G., Sellmann, D., \& Bogner, F. X. (2012). The influence of situational emotions on the intention for sustainable consumer behaviour in a student-centred intervention. Environmental Education Research(ahead-of-print), 1.

Geisser, S. (1975). The predictive sample reuse method with applications. Journal of the American Statistical Association, 320.

Glassman, T., Braun, R. E., Dodd, V. M., J, M., \& Miller, E. M. (2010). Using the theory of planned behavior to explain the drinking motivations of social, high-risk, and extreme drinkers on game day. Journal of Community Health, 35(2), 172.

Godin, G., \& Kok, G. (1996). The theory of planned behavior: A review of its applications to health-related behaviors. American Journal of Health Promotion, 11(2), 87.

Grace, D. (2007). How embarrassing! An exploratory study of critical incidents including affective reactions. Journal of Service Research, 9(3), 271.

Hair, J. F., Ringle, C. M., \& Sarstedt, M. (2011). PLS-SEM: Indeed a silver bullet. The Journal of Marketing Theory and Practice, 19(2), 139.

Han, H., \& Back, K.-J. (2007). Investigating the effects of consumption emotions on customer satisfaction and repeat visit intentions in the lodging industry. Journal of Hospitality \& Leisure Marketing, 15(3), 5.

Hausenblas, H. A., Carron, A. V., \& Mack, D. E. (1997). Application of the theories of reasoned action and planned behavior to exercise behavior: A meta-analysis. Journal of Sport and Exercise Psychology, 19(1), 36.

Hedman, J., \& Tscherning, H. (2010). Emotions and Intention to Buy: Applying Neuro-IS on the Adoption on the iPhone. Paper presented at the NeuroPsychoEconomics/ConNEcs Conference.

Heinhuis, D., \& Vries, E. J. (2009). Modelling Customer Behaviour in Multi-channel Service Distribution. Enterprise Applications and Services in the Finance Industry, 23, 47. doi:10.1007/978-3-642-01197-9_4

Henseler, J., Ringle, C. M., \& Sinkovics, R. R. (2009). The use of partial least squares path modeling in international marketing. Advances in international marketing, 20(1), 277.

Hulland, J. (1999). Use of partial least squares (PLS) in strategic management research: a review of four recent studies. Strategic Management Journal, 20(2), 195. 
Jang, S. S., \& Namkung, Y. (2009). Perceived quality, emotions, and behavioral intentions: Application of an extended Mehrabian-Russell model to restaurants. Journal of Business Research, 62(4), 451.

Jang, Y.-T. J., Chang, S. E., \& Chen, P.-A. (2013). Exploring Social Networking Sites for Facilitating Multi-Channel Retailing. Multimedia Tools and Aplications, 51(3), 1.

Jiménez, M. L. V., \& Fuertes, F. C. (2005). Positive emotions in volunteerism. The Spanish Journal of Psychology, 8(1), 30.

Katsanis, L. P. (1994). Do Unmentionable Products Still Exist?: An Empirical Investigation. Journal of Product \& Brand Management, 3(4), 5.

Keer, M., van den Putte, B., \& Neijens, P. (2012). The interplay between affect and theory of planned behavior variables. American Journal of Health Behavior, 36(1), 107.

Khoury, A. J., Moazzem, S. W., Jarjoura, C. M., Carothers, C., \& Hinton, A. (2005). Breastfeeding initiation in low-income women: role of attitudes, support, and perceived control. Women's Health Issues, 15(2), 64.

Kim, R. B., Park, K. S., Hong, D. Y., Lee, C. H., \& Kim, J. R. (2010). Factors associated with cancer screening intention in eligible persons for national cancer screening program. Journal of Preventive Medicine and Public Health, 43(1), 62.

King, T., \& Dennis, C. (2003). Interviews of deshopping behaviour: an analysis of theory of planned behaviour. International Journal of Retail \& Distribution Management, 31(3), 153.

Krones, T., Keller, H., Becker, A., Sönnichsen, A., Baum, E., \& Donner-Banzhoff, N. (2010). The theory of planned behaviour in a randomized trial of a decision aid on cardiovascular risk prevention. Patient education and counseling, 78(2), 169 . doi:DOI: 10.1016/j.pec.2009.06.010

Kwan, B. M., \& Bryan, A. D. (2010). Affective response to exercise as a component of exercise motivation: Attitudes, norms, self-efficacy, and temporal stability of intentions. Psychology of Sport and Exercise, 11(1), 71. doi:DOI: 10.1016/j.psychsport.2009.05.010

Kwon, W. S., \& Lennon, S. J. (2009). Reciprocal effects between multichannel retailers' offline and online brand images. Journal of Retailing, 85(3), 376.

Ladhari, R. (2009). Service quality, emotional satisfaction, and behavioural intentions: a study in the hotel industry. Managing Service Quality, 19(3), 308.

Lau-Gesk, L., \& Drolet, A. (2008). The publicly self-consciousness consumer: Prepared to be embarrassed. Journal of Consumer Psychology, 18(2), 127.

Lavoie, M., \& Godin, G. (1991). Correlates of intention to use condoms among auto mechanic students. Health education research, 6(3), 313.

Lee, J., \& Cerreto, F. A. (2010). Theory of planned behavior and teachers' decisions regarding use of educational technology \& Society. 13(1), 152.

Liang, H., Saraf, N., Hu, Q., \& Xue, Y. (2007). Assimilation of enterprise systems: the effect of institutional pressures and the mediating role of top management. MIS quarterly, 59-87.

Liao, C., Lin, H. N., \& Liu, Y. P. (2010). Predicting the use of pirated software: A contingency model integrating perceived risk with the theory of planned behavior. Journal of Business Ethics, 91(2), 237.

Liem, G. A. D., \& Bernardo, A. B. I. (2010). Epistemological beliefs and theory of planned behavior: Examining beliefs about knowledge and knowing as distal predictors of Indonesian tertiary students' intention to study. The Asia-Pacific Education Researcher, 19(1), 127. 
Lin, H.-F. (2008). Predicting consumer intentions to shop online: An empirical test of competing theories. Electronic Commerce Research and Applications, 6(4), 433.

Lindell, M. K., \& Whitney, D. J. (2001). Accounting for common method variance in crosssectional research designs. Journal of applied psychology, 86(1), 114.

Manning, M. (2009). The effects of subjective norms on behaviour in the theory of planned behaviour: A meta-analysis. British Journal of Social Psychology, 48(4), 649.

Miller, R. S., \& Leary, M. R. (1992). Social sources and interactive functions of emotion: The case of embarrassment (First Edition ed.): Sage Publications Inc.

Moons, I., \& De Pelsmacker, P. (2012). Emotions as determinants of electric car usage intention. Journal of Marketing Management, 28(3-4), 195.

Mooradian, T. A., \& Olver, J. M. (1997). “I can't get no satisfaction:” The impact of personality and emotion on postpurchase processes. Psychology \& Marketing, 14(4), 379.

Morton, N. A., \& Koufteros, X. (2008). Intention to commit online music piracy and its antecedents: an empirical investigation. Structural Equation Modeling, 15(3), 491.

Nair, V. K. (2007, 8-10 April, 2007). A Study on Purchase Pattern of Cosmetics among Consumers in Kerala. Paper presented at the International Marketing Conference on Marketing \& Society.

Nigbur, D., Lyons, E., \& Uzzell, D. (2010). Attitudes, norms, identity and environmental behaviour: Using an expanded theory of planned behaviour to predict participation in a kerbside recycling programme. British Journal of Social Psychology(49(2)), 259.

Nilsson, E., Gärling, T., Marell, A., \& Nordvall, A.-C. (2015). Who shops groceries where and how?-the relationship between choice of store format and type of grocery shopping. The International Review of Retail, Distribution and Consumer Research, 25(1), 1-19.

Otnes, C., \& McGrath, M. A. (2001). Perceptions and realities of male shopping behavior. Journal of Retailing, 77(1), 111.

Palmatier, R. W., Jarvis, C. B., Bechkoff, J. R., \& Kardes, F. R. (2009). The role of customer gratitude in relationship marketing. Journal of Marketing, 73(5), 1.

Pantano, E., \& Viassone, M. (2015). Engaging consumers on new integrated multichannel retail settings: Challenges for retailers. Journal of Retailing and Consumer Services, 25, 106114.

Parker, D., Manstead, A. S. R., \& Stradling, S. G. (1995). Extending the theory of planned behaviour: The role of personal norm. British Journal of Social Psychology, 34(2), 127.

Penz, E., \& Stottinger, B. (2005). Forget the" real" thing-take the copy! An explanatory model for the volitional purchase of counterfeit products. Advances in consumer research, 32, 568.

Podsakoff, P. M., MacKenzie, S. B., Lee, J.-Y., \& Podsakoff, N. P. (2003). Common method biases in behavioral research: a critical review of the literature and recommended remedies. Journal of applied psychology, 88(5), 879.

Pookulangara, S., Hawley, J., \& Xiao, G. (2011). Explaining consumers’ channel-switching behavior using the theory of planned behavior. Journal of Retailing and Consumer Services, 18(4), 311.

Reynolds, K. E., Folse, J. A. G., \& Jones, M. A. (2006). Search regret: antecedents and consequences. Journal of Retailing, 82(4), 339.

Richard, R., Pligt, J., \& Vries, N. (1995). Anticipated affective reactions and prevention of AIDS. British Journal of Social Psychology, 34(1), 9. 
Richard, R., van der Pligt, J., \& de Vries, N. (1996). Anticipated affect and behavioral choice. Basic and Applied Social Psychology, 18(2), 111.

Richins, M. L. (1997). Measuring emotions in the consumption experience. Journal of Consumer Research, 24(2), 127.

Rise, J. S. P., \& Hukkelberg, S. (2010). The role of self-identity in the theory of planned behavior: A meta-analysis. Journal of Applied Social Psychology, 40(5), 1085.

Ruby, L. A., \& Montagne, M. (1992). Direct-to-Consumer Advertising. Journal of pharmaceutical marketing \& management, 6(2), 21.

Sabini, J., Garvey, B., \& Hall, A. L. (2001). Shame and embarrassment revisited. Personality and Social Psychology Bulletin, 27(1), 104.

Sandberg, T., \& Conner, M. (2008). Anticipated regret as an additional predictor in the theory of planned behaviour: A meta-analysis. British Journal of Social Psychology, 47(4), 589.

Schuster, L. (2013). Consumers' behavioural responses toward technology-based social products.

Shankar, V., Inman, J. J., Mantrala, M., Kelley, E., \& Rizley, R. (2011). Innovations in Shopper Marketing: Current Insights and Future Research Issues. Journal of Retailing, 87, Supplement 1(0), S29. doi:10.1016/j.jretai.2011.04.007

Sheeran, P., \& Orbell, S. (1999). Augmenting the Theory of Planned Behavior: Roles for Anticipated Regret and Descriptive Norms1. Journal of Applied Social Psychology, 29(10), 2107.

Shim, S., \& Drake, M. F. (1990). Consumer intention to utilize electronic shopping: the Fishbein behavioral intention model. Journal of Direct Marketing, 4(3), 22.

Shim, S., Eastlick, M. A., Lotz, S. L., \& Warrington, P. (2001). An online prepurchase intentions model: The role of intention to search: Best Overall Paper Award-The Sixth Triennial AMS/ACRA Retailing Conference, 2000^. Journal of Retailing, 77(3), 397. doi:Doi: 10.1016/s0022-4359(01)00051-3

Steele, S. K., \& Porche, D. J. (2005). Testing the theory of planned behavior to predict mammography intention. Nursing research, 54(5), 332.

Steinbauer, A., \& Werthner, H. (2007). Consumer Behaviour in e-Tourism. Information and Communication Technologies in Tourism 2007, 65. doi:10.1007/978-3-211-69566-1_7

Stone, M. (1974). Cross-validatory choice and assessment of statistical predictions. Journal of the Royal Statistical Society.Series B (Methodological), 36(2), 111.

Swaid, S. (2007). Linking Perceived Electronic Service Quality and Service Loyalty on the Dimensional Level: An Aspect of Multi-Channel Services. AMCIS 2007 Proceedings. Paper 410.

van Birgelen, M., de Jong, A., \& de Ruyter, K. (2006). Multi-channel service retailing: The effects of channel performance satisfaction on behavioral intentions. Journal of Retailing, 82(4), 367-377. doi:http://dx.doi.org/10.1016/j.jretai.2006.08.010

Van den Putte, B. (1991). 20 years of the theory of reasoned action of Fishbein and Ajzen: A meta-analysis. Unpublished manuscript, University of Amsterdam.

Verhoef, P. C., Lemon, K. N., Parasuraman, A., Roggeveen, A., Tsiros, M., \& Schlesinger, L. A. (2009). Customer Experience Creation: Determinants, Dynamics and Management Strategies. Journal of Retailing, 85(1), 31-41. doi:http://dx.doi.org/10.1016/j.jretai.2008.11.001

Verhoef, P. C., Neslin, S. A., \& Vroomen, B. (2007). Multichannel customer management: Understanding the research-shopper phenomenon. International Journal of Research in Marketing, 24(2), 129. doi:DOI: 10.1016/j.ijresmar.2006.11.002 
Wang, E. S.-T. (2009). Displayed emotions to patronage intention: consumer response to contact personnel performance. The Service Industries Journal, 29(3), 317.

Wang, X. (2011). The role of anticipated negative emotions and past behavior in individuals' physical activity intentions and behaviors. Psychology of Sport and Exercise, 12(3), 300305.

Wang, X. (2013). Negotiating safer sex: A detailed analysis of attitude functions, anticipated emotions, relationship status and gender. Psychology \& health, 28(7), 800-817.

Wold, H. (1982). Soft modelling: the basic design and some extensions. Systems under indirect observation, Part II, 36.

Wolfinbarger, M., \& Gilly, M. (2000). Shopping online for freedom, control and even fun. Working paper California state Univeristy Long Beach.

Zayer, L. T., \& Neier, S. (2011). An exploration of men's brand relationships. Qualitative Market Research: An International Journal, 14(1), 83. 
Table 1: Studies that have used TPB in the context of channels and/or shopping behavior

\begin{tabular}{|c|c|c|}
\hline \multicolumn{3}{|c|}{ TPB-CHANNEL/SHOPPING STUDIES } \\
\hline Study/Author & Theory & Constructs \\
\hline $\begin{array}{l}\text { Consumer behavior in e- } \\
\text { tourism (Steinbauer \& } \\
\text { Werthner, 2007) }\end{array}$ & $\begin{array}{l}\text { IDT Information Diffusion } \\
\text { TRA Reasoned Action } \\
\text { TPB Planned Behavior } \\
\text { TAM Technology } \\
\text { Acceptance }\end{array}$ & $\begin{array}{l}\text { Attitude, involvement, } \\
\text { self-efficacy, trust, } \\
\text { evaluation of website, } \\
\text { travel motivation, trip } \\
\text { features, experience with } \\
\text { e-commerce, internet } \\
\text { affinity, e-tourism usage }\end{array}$ \\
\hline $\begin{array}{l}\text { Linking perceived electronic } \\
\text { service quality and service } \\
\text { loyalty on the dimensional } \\
\text { level: An aspect of } \\
\text { multichannel services (Swaid, } \\
\text { 2007) }\end{array}$ & $\begin{array}{l}\text { TAM } \\
\text { SERVQUAL } \\
\text { TRA }\end{array}$ & $\begin{array}{l}\text { Service quality and } \\
\text { service loyalty }\end{array}$ \\
\hline $\begin{array}{l}\text { Multichannel customer } \\
\text { management: Understanding } \\
\text { the research-shopper } \\
\text { phenomenon (Verhoef, Neslin, } \\
\text { \& Vroomen, 2007). }\end{array}$ & TRA & $\begin{array}{l}\text { Search/purchase } \\
\text { attributes } \\
\text { attractiveness } \\
\text { choice } \\
\text { Cross-channel synergies }\end{array}$ \\
\hline $\begin{array}{l}\text { An action strategy approach to } \\
\text { examining shopping behavior } \\
\text { (Darden \& Dorsch, 1990). }\end{array}$ & $\begin{array}{l}\text { TRA } \\
\text { TPB } \\
\text { Shopping Orientation }\end{array}$ & Action strategies \\
\hline $\begin{array}{l}\text { Reciprocal effects between } \\
\text { multichannel retailers’ offline } \\
\text { and online brand images (Kwon } \\
\text { \& Lennon, 2009) }\end{array}$ & $\begin{array}{l}\text { TRA } \\
\text { Cognitive dissonance }\end{array}$ & $\begin{array}{l}\text { Beliefs - attitudes - } \\
\text { intention }\end{array}$ \\
\hline $\begin{array}{l}\text { An online pre-purchase } \\
\text { intentions model: The role of } \\
\text { intention to search (Shim et al., } \\
\text { 2001) }\end{array}$ & $\begin{array}{l}\text { TPB } \\
\text { Pre-purchase consumer } \\
\text { information search }\end{array}$ & $\begin{array}{l}\text { Availability of a } \\
\text { computer, computer skills, } \\
\text { product knowledge, prior } \\
\text { experience, attitude } \\
\text { towards shopping, and } \\
\text { social influence, } \\
\text { information presentation } \\
\text { format, information flow } \\
\text { and media interactivity. }\end{array}$ \\
\hline $\begin{array}{l}\text { Predicting adolescents' use of } \\
\text { social networking sites from an } \\
\text { extended theory of planned } \\
\text { behavior perspective (Baker \& } \\
\text { White, 2010) }\end{array}$ & TPB & $\begin{array}{l}\text { Group norm } \\
\text { Self-esteem (face-to-face } \\
\text { versus e-mail) }\end{array}$ \\
\hline
\end{tabular}


Table 2: Studies that have explored the relationship between Emotions and Intention

\begin{tabular}{|l|l|}
\hline Path & Studies \\
\hline Emotions $\rightarrow$ & Bagozzi, Gopinath, \& Nyer (1999), Chapman \& Coups \\
Intentions & (2006), Jiménez \& Fuertes (2005), Babin \& Babin (1996), \\
& Bigné, Mattila, \& Andreu (2008), Jang \& Namkung (2009), \\
& Brown, Cron, \& Slocum Jr (1997), Mooradian \& Olver \\
& (1997), Bozinoff \& Ghingold (1983), Han \& Back (2007), \\
& Palmatier, Jarvis, Bechkoff, \& Kardes (2009), Ladhari (2009), \\
& Wang (2009), Chang (2010), Moons \& De Pelsmacker (2012), \\
& Hedman \& Tscherning (2010), Fröhlich, Sellmann, \& Bogner, \\
& (2012), Carrera, Caballero, \& Munoz (2012). \\
\hline
\end{tabular}

Table 3: Items used in the survey

\begin{tabular}{|l|l|l|l|}
\hline Construct & Source & $\begin{array}{l}\text { No. } \\
\text { of } \\
\text { Items }\end{array}$ & Scale \\
\hline Attitudes & $\begin{array}{l}\text { Ajzen (1991), Francis et al. (2004) } \\
\text { Osgood et al. (1957), Mehrabian \& } \\
\text { Russell (1974) }\end{array}$ & 10 & Likert \\
\hline Subjective Norm & Ajzen (1991), Francis et al. (2004) & 4 & Likert \\
\hline PBC & Ajzen (1991), Francis et al. (2004) & 3 & Likert \\
\hline Intention & Ajzen (1991), Francis et al. (2004) & 3 & Likert \\
\hline Emotions & Richins (1997), Reynolds et al. (2006) & 7 & Likert \\
\hline
\end{tabular}

Table 4: Descriptive Statistics for each construct:

\begin{tabular}{|l|c|c|c|c|c|c|}
\hline \multirow{2}{*}{ Construct } & \multicolumn{2}{|c|}{ DRUGSTORE } & \multicolumn{2}{c|}{ INTERNET } & \multicolumn{2}{c|}{ MULTI-CHANNEL } \\
\cline { 2 - 7 } \multicolumn{1}{c|}{ Mean } & $\begin{array}{c}\text { Standard } \\
\text { Deviation }\end{array}$ & Mean & $\begin{array}{c}\text { Standard } \\
\text { Deviation }\end{array}$ & $\begin{array}{c}\text { Standard } \\
\text { Deviation }\end{array}$ \\
\hline Attitude & 4,33 &, 60 & 5,07 & 1,04 & 4,73 & 1,21 \\
Subjective Norm & 4,13 & 1,10 & 4,11 & 1,16 & 3,95 &, 83 \\
PBC & 4,79 &, 88 & 4,75 & 1,23 & 4,20 &, 88 \\
Negative Emotions & 3,37 & 2,35 & 2,17 & 1,63 & 2,59 & 1,48 \\
\hline
\end{tabular}


Figure 1: Graphical representation of the Conceptual model - Total Sample

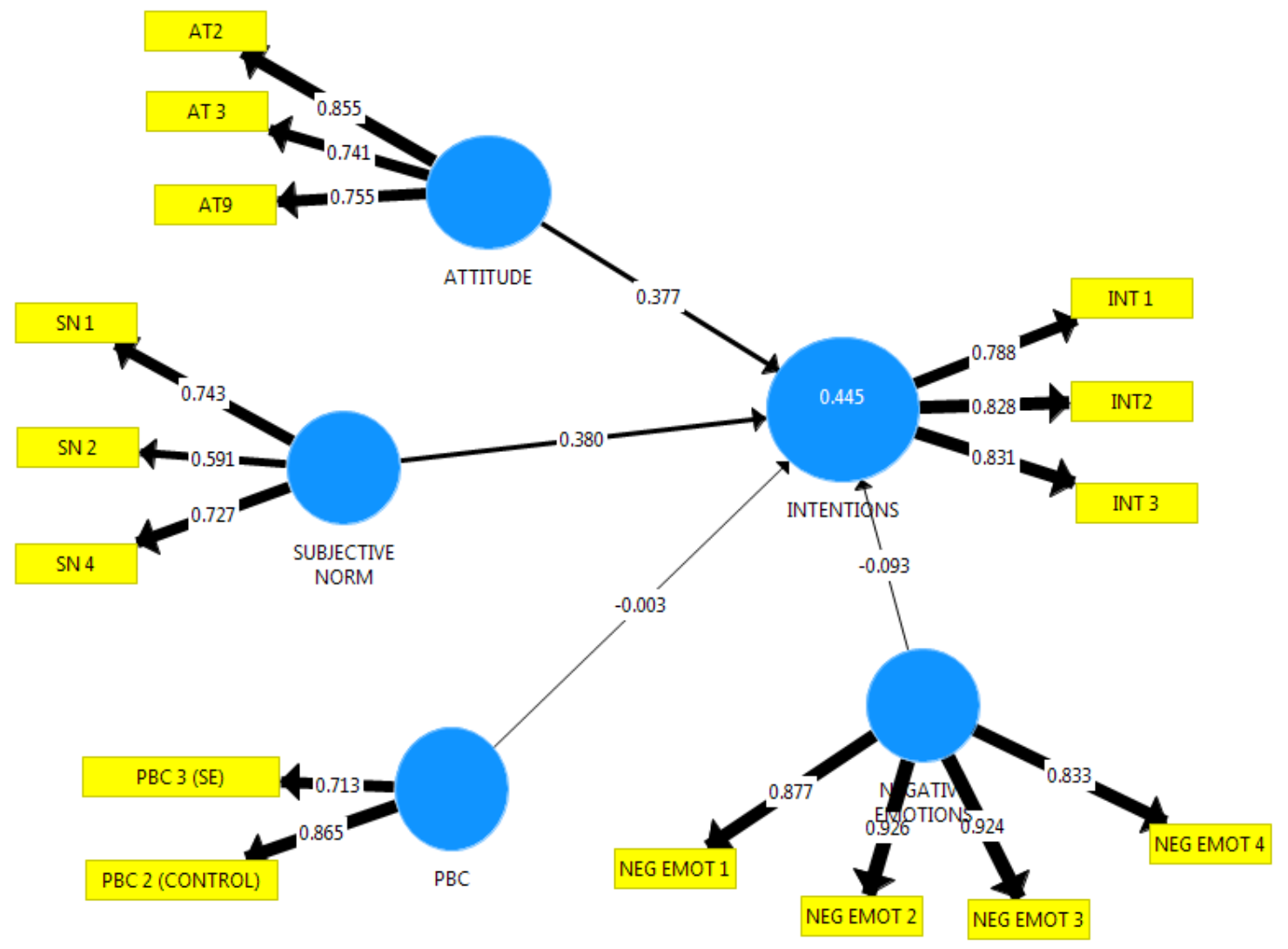


Figure 2: Graphical representation of the Conceptual model - Drugstore

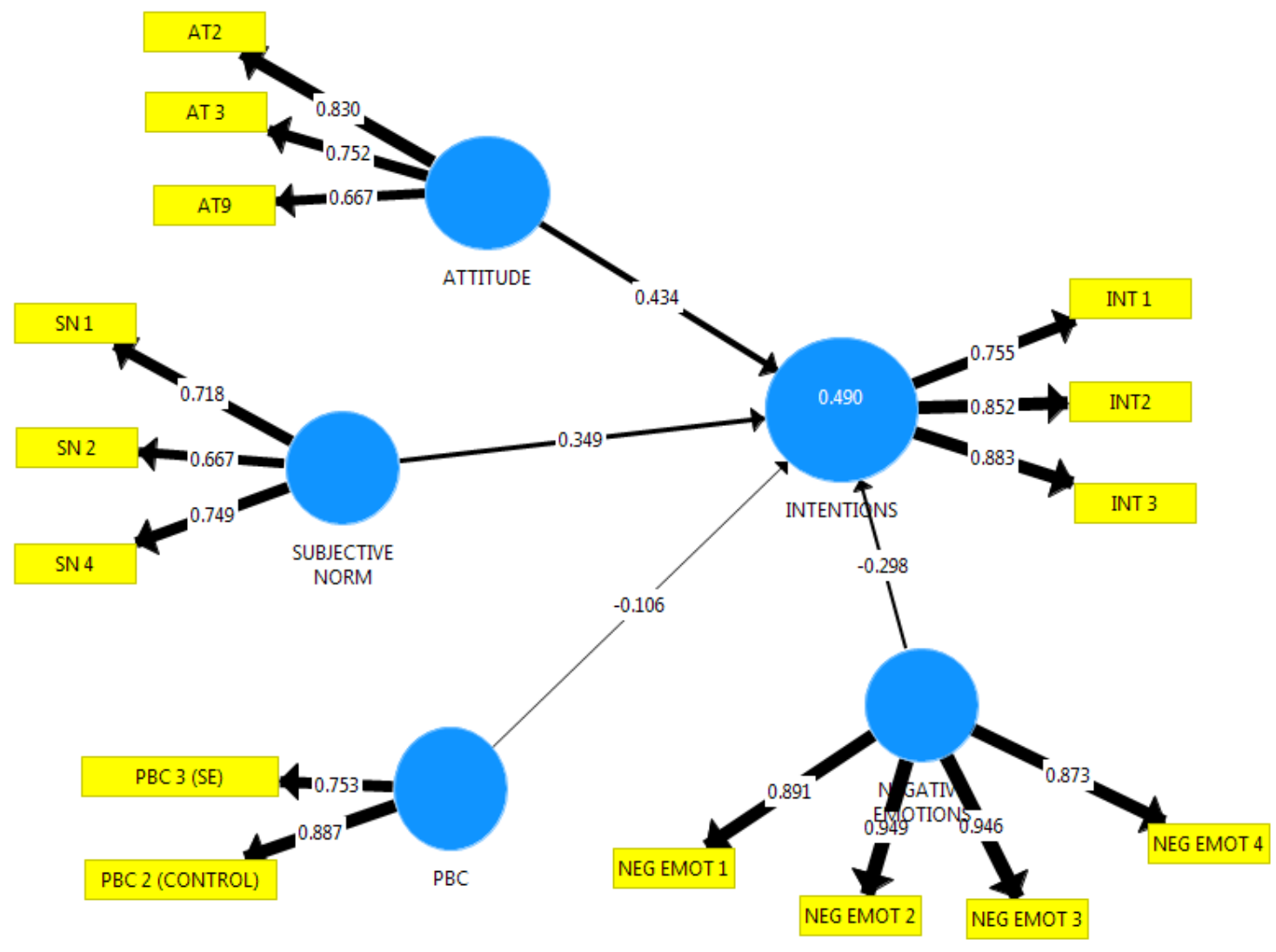


Figure 3: Graphical representation of the Conceptual model - Internet

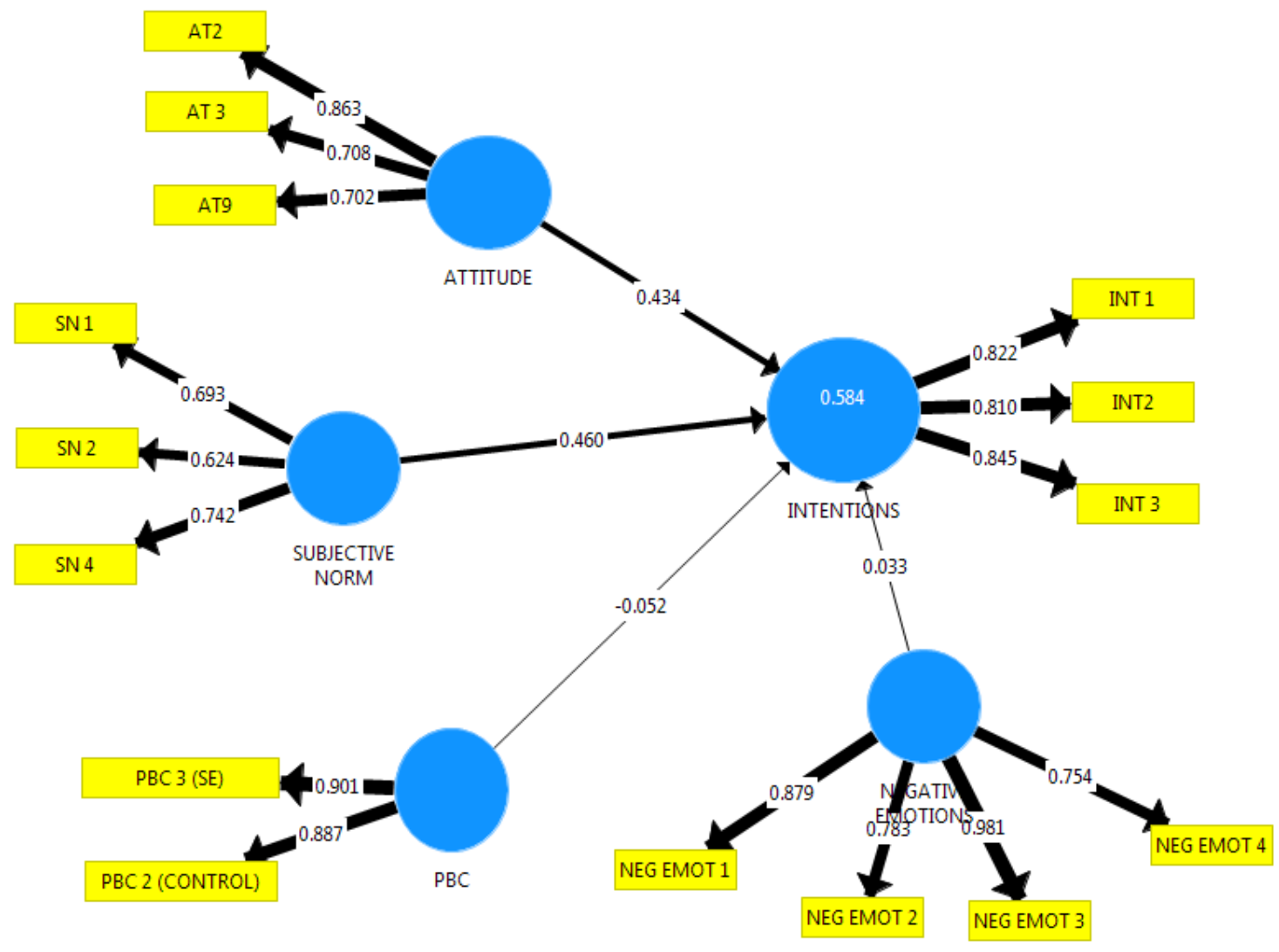


Figure 4: Graphical representation of the Conceptual model - Multi-channel

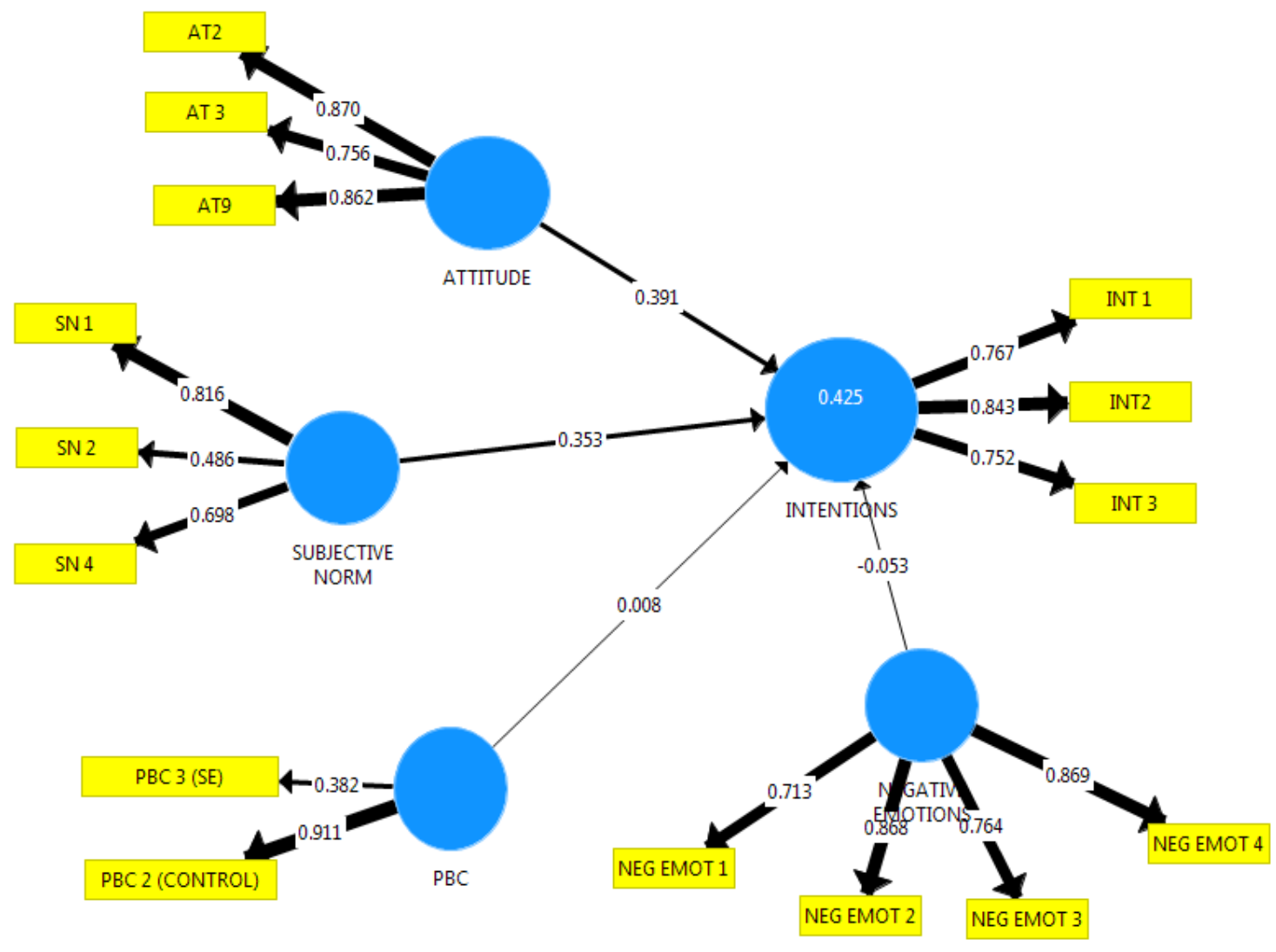


Table 5: Loadings, Weights, and Composite Reliability

\begin{tabular}{|c|c|c|c|}
\hline \multicolumn{4}{|c|}{ TOTAL SAMPLE } \\
\hline Construct & Item & Loading & $\mathrm{CR}$ \\
\hline \multirow[t]{3}{*}{ Attitude } & Att2 Foolish/ Wise & 0,85 & 0,83 \\
\hline & Att3 Changeable/Stable & 0,74 & \\
\hline & Att9 Useless/Useful & 0,76 & \\
\hline \multirow[t]{3}{*}{ SN } & SN1 (Important for me) & 0,74 & 0,73 \\
\hline & SN2 (most/suffer of hairloss) & 0,59 & \\
\hline & SN4 (people whose opinions I value) & 0,72 & \\
\hline \multirow[t]{2}{*}{ PBC } & PBC2 (Up to me) & 0,86 & 0,77 \\
\hline & PBC3 (If I wanted) & 0,71 & \\
\hline \multirow[t]{4}{*}{ ANE } & Ant. Neg. Emot 1(Embarrassed) & 0,88 & 0,94 \\
\hline & Ant.Neg. Emot 2(Nervous) & 0,93 & \\
\hline & Ant.Neg. Emot 3(Tense) & 0,92 & \\
\hline & Ant.Neg. Emot 4(Discontent) & 0,83 & \\
\hline \multirow[t]{3}{*}{ Intention } & Int 1 (I expect) & 0,79 & 0,86 \\
\hline & Int 2 (I want) & 0,83 & \\
\hline & Int 3 (I intend) & 0,83 & \\
\hline \multicolumn{4}{|c|}{ DRUGSTORE } \\
\hline Construct & Item & Loading & CR \\
\hline \multirow[t]{3}{*}{ Attitude } & Att2 Foolish/ Wise & 0,83 & 0,80 \\
\hline & Att3 Changeable/Stable & 0,75 & \\
\hline & Att9 Useless/Useful & 0,67 & \\
\hline \multirow[t]{3}{*}{ SN } & SN1 (Important for me) & 0,72 & \\
\hline & SN2 (most/suffer of hairloss) & 0,67 & 0,76 \\
\hline & SN4 (people whose opinions I value) & 0,74 & \\
\hline \multirow[t]{2}{*}{ PBC } & PBC2 (Up to me) & 0,89 & 0,80 \\
\hline & PBC3 (If I wanted) & 0,75 & \\
\hline \multirow[t]{4}{*}{ ANE } & Ant. Neg. Emot 1(Embarrassed) & 0,89 & 0,98 \\
\hline & Ant.Neg. Emot 2(Nervous) & 0,94 & \\
\hline & Ant.Neg. Emot 3(Tense) & 0,95 & \\
\hline & Ant.Neg. Emot 4(Discontent) & 0,87 & \\
\hline \multirow[t]{3}{*}{ Intention } & Int 1 (I expect) & 0,76 & 0,87 \\
\hline & Int 2 (I want) & 0,88 & \\
\hline & Int 3 (I intend) & 0,85 & \\
\hline \multicolumn{4}{|c|}{ INTERNET } \\
\hline Construct & Item & Loading & CR \\
\hline Attitude & Att2 Foolish/ Wise & 0,86 & 0,84 \\
\hline & Att3 Changeable/Stable & 0,71 & \\
\hline & Att9 Useless/Useful & 0,70 & \\
\hline SN & SN1 (Important for me) & 0,69 & 0,73 \\
\hline & SN2 (most/suffer of hairloss) & 0,62 & \\
\hline & SN4 (people whose opinions I value) & 0,74 & \\
\hline PBC & PBC2 (Up to me) & 0,89 & 0,89 \\
\hline & PBC3 (If I wanted) & 0,90 & \\
\hline ANE & Ant. Neg. Emot 1(Embarrassed) & 0,88 & 0,91 \\
\hline & Ant.Neg. Emot 2(Nervous) & 0,78 & \\
\hline & Ant.Neg. Emot 3(Tense) & 0,98 & \\
\hline & Ant.Neg. Emot 4(Discontent) & 0,75 & \\
\hline Intention & Int 1 (I expect) & 0,82 & 0,87 \\
\hline & Int 2 (I want) & 0,84 & \\
\hline & Int 3 (I intend) & 0,81 & \\
\hline & MULTICHANNEL & & \\
\hline Construct & Item & Loading & $\mathrm{CR}$ \\
\hline Attitude & Att2 Foolish/ Wise & 0,87 & 0,87 \\
\hline & Att3 Changeable/Stable & 0,75 & \\
\hline & Att9 Useless/Useful & 0,86 & \\
\hline SN & SN1 (Important for me) & 0,81 & 0,71 \\
\hline & SN2 (most/suffer of hairloss) & 0,48 & \\
\hline & SN4 (people whose opinions I value) & 0,69 & \\
\hline PBC & PBC2 (Up to me) & 0,91 & 0,62 \\
\hline & PBC3 (If I wanted) & 0,38 & \\
\hline ANE & Ant. Neg. Emot 1(Embarrassed) & 0,71 & 0,88 \\
\hline & Ant.Neg. Emot 2(Nervous) & 0,87 & \\
\hline & Ant.Neg. Emot 3(Tense) & 0,76 & \\
\hline & Ant.Neg. Emot 4(Discontent) & 0,86 & \\
\hline Intention & Int 1 (I expect) & 0,76 & 0,83 \\
\hline & Int 2 (I want) & 0,84 & \\
\hline & Int 3 (I intend) & 0,75 & \\
\hline
\end{tabular}


Table 6: Explained variance (R2) to Intention

\begin{tabular}{|l|c|}
\hline Intention & Explained variance (R2) \\
\hline Total Sample & 0,45 \\
Drugstore & 0,49 \\
Internet & 0,58 \\
Multi-channel & 0,43 \\
\hline
\end{tabular}


Table 7: Inter-construct correlations for SEs

\begin{tabular}{|l|l|l|l|l|l|}
\hline \multicolumn{7}{|c|}{ TOTAL SAMPLE } \\
\hline & ATT & INT & ANE & PBC & SN \\
\hline ATTITUDE & 0.785 & & & & \\
\hline INTENTIONS & 0.571 & 0.816 & & & \\
\hline NEGATIVE EMOTIONS & -0.221 & -0.196 & 0.891 & & \\
\hline PBC & 0.456 & 0.275 & -0.140 & 0.793 & \\
\hline SUBJECTIVE NORM & 0.457 & 0.557 & -0.052 & 0.244 & 0.690 \\
\hline
\end{tabular}

\begin{tabular}{|l|l|l|l|l|l|}
\hline \multicolumn{7}{|c|}{ DRUGSTORE } \\
\hline & ATT & INT & ANE & PBC & SN \\
\hline ATTITUDE & 0.753 & & & & \\
\hline INTENTIONS & 0.563 & 0.832 & & & \\
\hline NEGATIVE EMOTIONS & -0.184 & -0.359 & 0.915 & & \\
\hline PBC & 0.623 & 0.294 & -0.113 & 0.823 & \\
\hline SUBJECTIVE NORM & 0.401 & 0.488 & 0.018 & 0.275 & 0.712 \\
\hline
\end{tabular}

\begin{tabular}{|l|l|l|l|l|l|}
\hline \multicolumn{7}{|c|}{ INTERNET } \\
\hline & ATT & INT & ANE & PBC & SN \\
\hline ATTITUDE & 0.761 & & & & \\
\hline INTENTIONS & 0.661 & 0.826 & & & \\
\hline NEGATIVE EMOTIONS & -0.240 & -0.093 & 0.854 & & \\
\hline PBC & 0.541 & 0.327 & -0.311 & 0.894 & \\
\hline SUBJECTIVE NORM & 0.572 & 0.688 & -0.082 & 0.336 & 0.688 \\
\hline
\end{tabular}

\begin{tabular}{|l|l|l|l|l|l|}
\hline \multicolumn{7}{|c|}{ MULTICHANNEL } \\
\hline & ATT & INT & ANE & PBC & SN \\
\hline ATTITUDE & 0.831 & & & & \\
\hline INTENTIONS & 0.565 & 0.788 & & & \\
\hline NEGATIVE EMOTIONS & -0.294 & -0.233 & 0.806 & & \\
PBC & 0.333 & 0.206 & -0.125 & 0.698 & \\
\hline SUBJECTIVE NORM & 0.442 & 0.537 & -0.182 & 0.174 & 0.681 \\
\hline
\end{tabular}


Table 8: Item level inter-correlations (Total sample)

\begin{tabular}{|l|c|c|c|c|c|}
\hline \multicolumn{1}{|c|}{ Item } & ATT & INTENT & ANE & PBC & SN \\
\hline AT 3 & $\mathbf{0 . 7 4 1}$ & 0.415 & -0.099 & 0.343 & 0.308 \\
\hline AT2 & $\mathbf{0 . 8 5 5}$ & 0.514 & -0.192 & 0.389 & 0.425 \\
AT9 & $\mathbf{0 . 7 5 5}$ & 0.406 & -0.229 & 0.340 & 0.335 \\
\hline INT 1 & 0.411 & $\mathbf{0 . 7 8 8}$ & -0.090 & 0.191 & 0.524 \\
INT 3 & 0.447 & $\mathbf{0 . 8 3 1}$ & -0.133 & 0.201 & 0.410 \\
\hline INT2 & 0.532 & $\mathbf{0 . 8 2 8}$ & -0.248 & 0.276 & 0.427 \\
\hline NEG EMOT 1 & -0.150 & -0.108 & $\mathbf{0 . 8 7 7}$ & -0.165 & -0.038 \\
\hline NEG EMOT 2 & -0.184 & -0.205 & $\mathbf{0 . 9 2 6}$ & -0.098 & -0.060 \\
NEG EMOT 3 & -0.237 & -0.177 & $\mathbf{0 . 9 2 4}$ & -0.129 & -0.023 \\
NEG EMOT 4 & -0.201 & -0.178 & $\mathbf{0 . 8 3 3}$ & -0.128 & -0.060 \\
PBC 2 (CONTROL) & 0.409 & 0.250 & -0.105 & $\mathbf{0 . 8 6 5}$ & 0.235 \\
PBC 3 (SE) & 0.304 & 0.179 & -0.122 & $\mathbf{0 . 7 1 3}$ & 0.140 \\
SN 1 & 0.346 & 0.429 & -0.054 & 0.164 & $\mathbf{0 . 7 4 3}$ \\
SN 2 & 0.332 & 0.315 & -0.029 & 0.213 & $\mathbf{0 . 5 9 1}$ \\
SN 4 & 0.278 & 0.400 & -0.023 & 0.142 & $\mathbf{0 . 7 2 7}$ \\
\hline
\end{tabular}

Table 9: Item level inter-correlations (Drugstore)

\begin{tabular}{|l|c|c|c|c|c|}
\hline \multicolumn{1}{|c|}{ Item } & ATT & INTENT & ANE & PBC & SN \\
\hline AT 3 & $\mathbf{0 . 7 5 2}$ & 0.399 & -0.163 & 0.575 & 0.221 \\
AT2 & $\mathbf{0 . 8 3 0}$ & 0.513 & -0.110 & 0.532 & 0.470 \\
AT9 & $\mathbf{0 . 6 6 7}$ & 0.333 & -0.161 & 0.265 & 0.152 \\
\hline INT 1 & 0.483 & $\mathbf{0 . 7 5 5}$ & -0.116 & 0.203 & 0.439 \\
\hline INT 3 & 0.492 & $\mathbf{0 . 8 8 3}$ & -0.331 & 0.195 & 0.417 \\
INT2 & 0.431 & $\mathbf{0 . 8 5 2}$ & -0.435 & 0.336 & 0.366 \\
\hline NEG EMOT 1 & -0.128 & -0.270 & $\mathbf{0 . 8 9 1}$ & -0.147 & 0.002 \\
NEG EMOT 2 & -0.188 & -0.376 & $\mathbf{0 . 9 4 9}$ & -0.102 & 0.005 \\
NEG EMOT 3 & -0.198 & -0.353 & $\mathbf{0 . 9 4 6}$ & -0.087 & 0.017 \\
NEG EMOT 4 & -0.149 & -0.300 & $\mathbf{0 . 8 7 3}$ & -0.088 & 0.044 \\
PBC 2 (CONTROL) & 0.470 & 0.279 & -0.056 & $\mathbf{0 . 8 8 7}$ & 0.228 \\
PBC 3 (SE) & 0.587 & 0.196 & -0.149 & $\mathbf{0 . 7 5 3}$ & 0.229 \\
SN 1 & 0.260 & 0.386 & 0.067 & 0.252 & $\mathbf{0 . 7 1 8}$ \\
SN 2 & 0.484 & 0.330 & -0.119 & 0.300 & $\mathbf{0 . 6 6 7}$ \\
SN 4 & 0.108 & 0.318 & 0.084 & 0.017 & $\mathbf{0 . 7 4 9}$ \\
\hline
\end{tabular}


Table 10: Item level inter-correlations (Internet)

\begin{tabular}{|l|c|c|c|c|c|}
\hline \multicolumn{1}{|c|}{ Item } & ATT & INTENT & ANE & PBC & SN \\
\hline AT 3 & $\mathbf{0 . 7 0 8}$ & 0.466 & -0.056 & 0.230 & 0.427 \\
\hline AT2 & $\mathbf{0 . 8 6 3}$ & 0.620 & -0.178 & 0.498 & 0.448 \\
\hline AT9 & $\mathbf{0 . 7 0 2}$ & 0.389 & -0.352 & 0.514 & 0.448 \\
\hline INT 1 & 0.506 & $\mathbf{0 . 8 2 2}$ & -0.051 & 0.248 & 0.649 \\
INT 3 & 0.508 & $\mathbf{0 . 8 4 5}$ & -0.087 & 0.281 & 0.541 \\
\hline INT2 & 0.622 & $\mathbf{0 . 8 1 0}$ & -0.093 & 0.283 & 0.508 \\
\hline NEG EMOT 1 & -0.181 & -0.032 & $\mathbf{0 . 8 7 9}$ & -0.312 & -0.089 \\
\hline NEG EMOT 2 & -0.109 & -0.006 & $\mathbf{0 . 7 8 3}$ & -0.132 & -0.159 \\
NEG EMOT 3 & -0.238 & -0.118 & $\mathbf{0 . 9 8 1}$ & -0.291 & -0.063 \\
NEG EMOT 4 & -0.218 & -0.029 & $\mathbf{0 . 7 5 4}$ & -0.269 & -0.096 \\
PBC 2 (CONTROL) & 0.445 & 0.284 & -0.203 & $\mathbf{0 . 8 8 7}$ & 0.313 \\
\hline PBC 3 (SE) & 0.520 & 0.301 & -0.349 & $\mathbf{0 . 9 0 1}$ & 0.288 \\
\hline SN 1 & 0.338 & 0.449 & -0.196 & 0.124 & $\mathbf{0 . 6 9 3}$ \\
SN 2 & 0.300 & 0.407 & 0.042 & 0.176 & $\mathbf{0 . 6 2 4}$ \\
SN 4 & 0.514 & 0.550 & -0.016 & 0.362 & $\mathbf{0 . 7 4 2}$ \\
\hline
\end{tabular}

Table 11: Item level inter-correlations (Multichannel)

\begin{tabular}{|c|c|c|c|c|c|}
\hline Item & ATT & INTENT & ANE & PBC & SN \\
\hline AT 3 & 0.756 & 0.407 & -0.163 & 0.291 & 0.268 \\
\hline AT2 & 0.870 & 0.440 & -0.414 & 0.258 & 0.422 \\
\hline AT9 & 0.862 & 0.545 & -0.170 & 0.284 & 0.400 \\
\hline INT 1 & 0.305 & 0.767 & -0.255 & 0.132 & 0.499 \\
\hline INT 3 & 0.408 & 0.752 & 0.095 & 0.109 & 0.299 \\
\hline INT2 & 0.585 & 0.843 & -0.311 & 0.223 & 0.454 \\
\hline NEG EMOT 1 & -0.163 & -0.009 & 0.713 & -0.164 & -0.043 \\
\hline NEG EMOT 2 & -0.274 & -0.203 & 0.868 & -0.183 & -0.115 \\
\hline NEG EMOT 3 & -0.251 & -0.015 & 0.764 & -0.059 & -0.022 \\
\hline NEG EMOT 4 & -0.239 & -0.219 & 0.869 & -0.040 & $-0.20 s$ \\
\hline PBC 2 (CONTROL) & 0.394 & 0.186 & -0.128 & 0.911 & 0.235 \\
\hline PBC 3 (SE) & -0.075 & 0.083 & -0.018 & 0.382 & -0.104 \\
\hline SN 1 & 0.415 & 0.463 & -0.159 & 0.175 & 0.816 \\
\hline SN 2 & 0.234 & 0.255 & 0.036 & 0.154 & 0.486 \\
\hline SN 4 & 0.221 & 0.346 & -0.205 & 0.026 & 0.698 \\
\hline
\end{tabular}

Table 12: Path coefficients and their significances

\begin{tabular}{|c|c|c|c|c|c|c|c|c|c|c|c|c|c|c|}
\hline & & & \multicolumn{3}{|c|}{ TOTAL SAMPLE } & \multicolumn{3}{|c|}{ DRUGSTORE } & \multicolumn{3}{|c|}{ INTERNET } & \multicolumn{3}{|c|}{ MULTICHANNEL } \\
\hline Path & Hypothesis & & Coefficient & T Statistic & Sig. & Coefficient & T Statistic & Sig. & Coefficient & T Statistic & Sig. & Coefficient & T Statistic & Sig. \\
\hline ATT $>>$ INTENT & 1 & Supported & 0.377 & 5.209 & 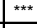 & 0.434 & 3.278 & 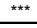 & 0.434 & 3.099 & *** & 0.391 & 2.662 & *** \\
\hline SN -> INTENT & 2 & Supported & 0.380 & 6.346 & 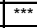 & 0.349 & 3.398 & 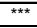 & 0.460 & 4.617 & 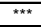 & 0.353 & 2.817 & 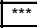 \\
\hline PBC -> INTENT & 3 & Not supported & -0.003 & 0.043 & & -0.106 & 0.833 & & -0.052 & 0.412 & & 0.008 & 0.060 & \\
\hline ANE $>>$ INTENT & 4 & Partialy supported & -0.093 & 1.762 & * & -0.298 & 3.486 & 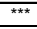 & 0.033 & 0.314 & & -0.053 & 0.350 & \\
\hline
\end{tabular}


Table 14: Effect sizes and predictive relevance

\begin{tabular}{|c|c|c|c|c|c|c|c|c|c|}
\hline & \multicolumn{3}{|c|}{ TOTAL SAMPLE } & \multicolumn{2}{|c|}{ DRUGSTORE } & \multicolumn{2}{|c|}{ INTERNET } & \multicolumn{2}{|c|}{ MULTICHANNEL } \\
\hline & T Statistics & P Values & & T Statistics & P Values & T Statistics & P Values & T Statistics & P Values \\
\hline ATTITUDE ->INTENTIONS & 2.183 & 0.029 & $* * *$ & 1.428 & 0.153 & 1.305 & 0.192 & 0.978 & 0.328 \\
\hline SUBJECTIVE NORM ->INTENTIONS & 2.595 & 0.009 & $* * *$ & 1.237 & 0.216 & 1.714 & 0.087 & 0.874 & 0.382 \\
\hline PBC ->INTENTIONS & 0.001 & 0.999 & & 0.331 & 0.740 & 0.118 & 0.906 & 0.002 & 0.999 \\
\hline NEGATIVE EMOTIONS ->INTENTIONS & 0.714 & 0.475 & & 1.238 & 0.216 & 0.050 & 0.960 & 0.071 & 0.943 \\
\hline
\end{tabular}

Table 15: Results of the Multi-Group Analysis.

\begin{tabular}{|c|c|c|c|c|c|c|}
\hline & \multicolumn{3}{|c|}{ DRUGSTORE vS INTERNET } & \multicolumn{3}{|c|}{ DRUGSTORE VS MULTICHANNEL } \\
\hline & Path Coefficients-diff & p-Value & & Path Coefficients-diff & $p$-Value & \\
\hline ATTITUDE -> INTENTIONS & 0.000 & 0.510 & & 0.043 & 0.422 & \\
\hline NEGATIVE EMOTIONS -> INTENTIONS & 0.331 & 0.992 & *** & 0.245 & 0.948 & *** \\
\hline PBC $->$ INTENTIONS & 0.054 & 0.613 & & 0.114 & 0.734 & \\
\hline SUBJECTIVE NORM -> INTENTIONS & 0.111 & 0.785 & & 0.004 & 0.506 & \\
\hline
\end{tabular}

Appendix A: Questionnaire used for the Drugstore Channel. 
Thank you very much for agreeing to participate in this survey! My name is Juan Carlos Londono and this study is part of my PhD thesis at Stirling University. The information provided by you will be used for research purposes and will not be used in a manner which would allow identification of your individual responses. The target sample for this survey is the general population of males. There will be some questions about a product called Regaine or Rogaine (you do not need to be a user or have purchased this product). If you have not heard about Regaine but still want to participate, the researcher will provide you with some product information. You were randomly selected to participate in this survey. If you want to participate to win $\mathrm{f} 100$ in Amazon vouchers as a token of our appreciation please leave us your email in the last question! This survey should take around 15 minutes. *Please make sure to answer all items - do not omit any.

How would you classify yourself?

Did not know what is Regaine, just heard about it.

Had heard of Regaine before yesterday but have never used it

Using Regaine 1-15 Weeks

Using Regaine for over 16 Weeks

Used Regaine in the past but not currently using it

Have you purchased $\underline{\mathbf{A N Y}}$ product in a high street (HS) drugstore during the last year?

No Yes

Please answer each of the following questions by circling the number that best describes your opinion. Some of the questions may appear to be similar, but they do address somewhat different issues.

In this survey the word SHOP represents your efforts to search for information and the act of purchasing Regaine. To what extent would you feel optimism if you shop for Regaine from a Boots High Street(HS) Drugstore $\begin{array}{lllllllllll}\text { Not at all } & & 1 & 2 & 3 & 4 & 5 & 6 & 7 & 8 & 9 \\ \text { Very Much }\end{array}$

To what extent would you feel no emotion if you shop for Regaine on a Boots HS Drugstore $\begin{array}{lllllllllll}\text { Not at all } & 1 & 2 & 3 & 4 & 5 & 6 & 7 & 8 & 9 \text { Very Much }\end{array}$

To what extent would you feel contentment if you shop for Regaine on a Boots HS Drugstore $\begin{array}{lllllllllll}\text { Not at all } & 1 & 2 & 3 & 4 & 5 & 6 & 7 & 8 & 9 & \text { Very Much }\end{array}$

To what extent would you feel embarrassed if you shop for Regaine on a Boots HS Drugstore $\begin{array}{llllllllll}\text { Not at all } & 1 & 2 & 3 & 4 & 5 & 6 & 7 & 8 & 9\end{array}$ Very Much

To what extent would you feel nervous if you shop for Regaine on a Boots HS Drugstore $\begin{array}{lllllllllll}\text { Not at all } & 1 & 2 & 3 & 4 & 5 & 6 & 7 & 8 & 9 & \text { Very Much }\end{array}$

To what extent would you feel tense if you shop for Regaine on a Boots HS Drugstore $\begin{array}{llllllllll}\text { Not at all } & 1 & 2 & 3 & 4 & 5 & 6 & 7 & 8 & 9\end{array}$ Very Much

To what extent would you feel discontent if you shop for Regaine on a Boots HS Drugstore $\begin{array}{llllllllll}\text { Not at all } & 1 & 2 & 3 & 4 & 5 & 6 & 7 & 8 & 9\end{array}$ Very Much

Shopping easily for Regaine on a Boots HS Extremely $\begin{array}{lllll}-3 & -2 & -1 & 0+1+2+3 & \text { Extremely }\end{array}$ drugstore is: undesirable desirable

Shopping for Regaine on a Boots HS drugstore that Extremely is close to me is: undesirable

\section{$\begin{array}{lllllll}-3 & -2 & -1 & 0 & +1 & +2 & +3\end{array}$ Extremely} desirable

Shopping rapidly for Regaine on a Boots HS drugstore is:

Shopping for Regaine on a Boots HS drugstore without having quality concerns is:

Extremely undesirable

$\begin{array}{llllllll}-3 & -2 & -1 & 0 & +1 & +2 & +3 & \text { Extremely }\end{array}$

desirable

\begin{tabular}{|c|c|}
\hline $\begin{array}{l}\text { Extremely } \\
\text { undesirable }\end{array}$ & $\begin{array}{lllllll}-3 & -2 & -1 & 0 & +1 & +2 & +3\end{array}$ \\
\hline
\end{tabular}

For me to pay a little more to shop for Regaine on a Boots HS drugstore instead of the internet is:

$\begin{array}{llllllll}\text { Unacceptable } & -3 & -2 & -1 & 0 & +1 & +2 & +3\end{array}$ Acceptable

During the last six months, how many bottles of Regaine have you purchased using Boots drugstore?

Please put an " $\mathrm{X}$ " on the blank that best reflects your opinion. If I had to purchase Regaine from Boots, I will do it:

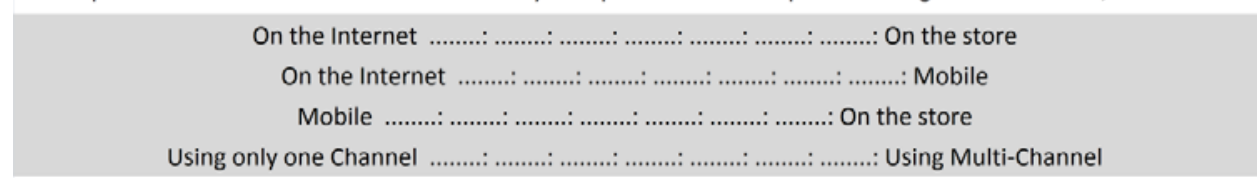

Please rank from 1 to 3 the following Channels according to the likelihood that you will use them as a channel to purchase Regaine from Boots: 


\begin{tabular}{|c|c|c|c|c|c|c|c|c|c|}
\hline $\begin{array}{l}\text { There are external factors that make it difficult to } \\
\text { shop for Regaine on a Boots Drugstore. }\end{array}$ & strongly disagree & 1 & 2 & 3 & 4 & 5 & 6 & 7 & strongly agree \\
\hline \multirow{2}{*}{$\begin{array}{l}\text { Most of the people who are important for me } \\
\text { would think that }\end{array}$} & I should not & 1 & 2 & 3 & 4 & 5 & 6 & 7 & I should \\
\hline & \multicolumn{9}{|c|}{ Shop for Regaine using Boots H.S. Drugstore } \\
\hline Shopping for Regaine on a Boots H.S drugstore is & Good & 1 & 2 & 3 & 4 & 5 & 6 & 7 & Bad \\
\hline $\begin{array}{l}\text { I expect to shop for Regaine on a Boots H.S } \\
\text { Drugstore }\end{array}$ & strongly disagree & 1 & 2 & 3 & 4 & 5 & 6 & 7 & strongly agree \\
\hline $\begin{array}{l}\text { Whether or not I shop for Regaine from Boots H.S } \\
\text { drugstore is completely up to me }\end{array}$ & strongly disagree & 1 & 2 & 3 & 4 & 5 & 6 & 7 & strongly agree \\
\hline $\begin{array}{l}\text { Most of the people who suffer from hair loss } \\
\text { shop for Regaine on a regular basis using Boots } \\
\text { H.S. Drugstore. }\end{array}$ & strongly disagree & 1 & 2 & 3 & 4 & 5 & 6 & 7 & strongly agree \\
\hline $\begin{array}{l}\text { Shopping for Regaine from Boots using its H.S } \\
\text { drugstore is }\end{array}$ & Foolish & 1 & 2 & 3 & 4 & 5 & 6 & 7 & Wise \\
\hline $\begin{array}{l}\text { I want to shop for Regaine on Boots using the H.S } \\
\text { Drugstore }\end{array}$ & strongly disagree & 1 & 2 & 3 & 4 & 5 & 6 & 7 & strongly agree \\
\hline $\begin{array}{l}\text { I am confident that if I wanted to, I could shop } \\
\text { for Regaine on Boots using the H.S drugstore }\end{array}$ & definitely false & 1 & 2 & 3 & 4 & 5 & 6 & 7 & definitely true \\
\hline $\begin{array}{l}\text { It is expected by others that I shop for Regaine } \\
\text { on a regular basis using Boots H.S. Drugstore }\end{array}$ & definitely false & 1 & 2 & 3 & 4 & 5 & 6 & 7 & definitely true \\
\hline $\begin{array}{l}\text { Shopping for Regaine on Boots using its H.S } \\
\text { drugstore is }\end{array}$ & Changeable & 1 & 2 & 3 & 4 & 5 & 6 & 7 & Stable \\
\hline $\begin{array}{l}\text { I intend to shop for Regaine on Boots using the } \\
\text { H.S Drugstore }\end{array}$ & strongly disagree & 1 & 2 & 3 & 4 & 5 & 6 & 7 & strongly agree \\
\hline $\begin{array}{l}\text { Shopping for Regaine on Boots using the HS } \\
\text { drugstore is something }\end{array}$ & Public & 1 & 2 & 3 & 4 & 5 & 6 & 7 & Private \\
\hline $\begin{array}{l}\text { Most people whose opinions I value would } \\
\text { approve that I shop for Regaine on Boots H.S. } \\
\text { drugstore on a regular basis }\end{array}$ & Strongly disagree & 1 & 2 & 3 & 4 & 5 & 6 & 7 & Strongly agree \\
\hline $\begin{array}{l}\text { Shopping for Regaine on Boots using its H.S } \\
\text { drugstore is }\end{array}$ & Calm & 1 & 2 & 3 & 4 & 5 & 6 & 7 & Excited \\
\hline $\begin{array}{l}\text { Shopping for Regaine on Boots using the HS } \\
\text { drugstore is }\end{array}$ & Unpleasant & 1 & 2 & 3 & 4 & 5 & 6 & 7 & Pleasant \\
\hline $\begin{array}{l}\text { Shopping for Regaine on Boots using the HS } \\
\text { drugstore is }\end{array}$ & Unenjoyable & 1 & 2 & 3 & 4 & 5 & 6 & 7 & Enjoyable \\
\hline $\begin{array}{l}\text { Shopping for Regaine on Boots using the HS } \\
\text { drugstore is }\end{array}$ & Constrained & 1 & 2 & 3 & 4 & 5 & 6 & 7 & Free \\
\hline $\begin{array}{l}\text { Shopping for Regaine on Boots using the HS } \\
\text { drugstore is }\end{array}$ & Useless & 1 & 2 & 3 & 4 & 5 & 6 & 7 & Useful \\
\hline $\begin{array}{l}\text { Shopping for Regaine on Boots using the HS } \\
\text { drugstore is }\end{array}$ & Complex & 1 & 2 & 3 & 4 & 5 & 6 & 7 & Simple \\
\hline $\begin{array}{l}\text { Generally speaking, how much do you care what } \\
\text { your parents/family think you should do? }\end{array}$ & Not at all & 1 & 2 & 3 & 4 & 5 & 6 & 7 & Very Much \\
\hline $\begin{array}{l}\text { Generally speaking, how much do you care what } \\
\text { your wife/girlfriend/partner think you should } \\
\text { dn? }\end{array}$ & Not at all & 1 & 2 & 3 & 4 & 5 & 6 & 7 & Very Much \\
\hline $\begin{array}{l}\text { Generally speaking, how much do you care what } \\
\text { your pharmacist think you should do? }\end{array}$ & Not at all & 1 & 2 & 3 & 4 & 5 & 6 & 7 & Very Much \\
\hline $\begin{array}{l}\text { If I feel that shopping for Regaine from Boots } \\
\text { using the Drugstore is the easiest, I will choose } \\
\text { the HS ctore }\end{array}$ & Unlikely & 1 & 2 & 3 & 4 & 5 & 6 & 7 & Likely \\
\hline $\begin{array}{l}\text { If I have a Boots H.S drugstore very close to my } \\
\text { work/home, I will use it to shop for Regaine. }\end{array}$ & Unlikely & 1 & 2 & 3 & 4 & 5 & 6 & 7 & Likely \\
\hline $\begin{array}{l}\text { If I feel that shopping for Regaine from Boots } \\
\text { using the drugstore is the fasters, I will choose } \\
\text { the H.S. store. }\end{array}$ & Unlikely & 1 & 2 & 3 & 4 & 5 & 6 & 7 & Likely \\
\hline $\begin{array}{l}\text { If I feel there are no quality concerns when } \\
\text { shopping from Boots H.S. drugstore, I will choose } \\
\text { it for purchase. }\end{array}$ & Unlikely & 1 & 2 & 3 & 4 & 5 & 6 & 7 & Likely \\
\hline $\begin{array}{l}\text { If I feel there is only a little more expensive to } \\
\text { shop from Boots H.S. drugstore compared with } \\
\text { the internet or catalogue, I will choose it for }\end{array}$ & Unlikely & 1 & 2 & 3 & 4 & 5 & 6 & 7 & Likely \\
\hline $\begin{array}{l}\text { How often do you see Regaine Exhibited in Boots } \\
\text { Drugstore? }\end{array}$ & Never & 1 & 2 & 3 & 4 & 5 & 6 & 7 & Always \\
\hline $\begin{array}{l}\text { How often are you find yourself within a walking } \\
\text { distance of a Boots Drugstore? }\end{array}$ & Never & 1 & 2 & 3 & 4 & 5 & 6 & 7 & Always \\
\hline $\begin{array}{l}\text { How often do you feel embarrassed about } \\
\text { purchasing Regaine at Boots Drugstore }\end{array}$ & Never & 1 & 2 & 3 & 4 & 5 & 6 & 7 & Always \\
\hline $\begin{array}{l}\text { How often do you find good customer service } \\
\text { when purchasing Regaine at Boots HS Drugstore? }\end{array}$ & Never & 1 & 2 & 3 & 4 & 5 & 6 & 7 & Always \\
\hline $\begin{array}{l}\text { If I did not see Regaine exhibited in Boots HS } \\
\text { drugstore, it would make it more difficult for me } \\
\text { to shop for it. }\end{array}$ & Strongly Disagree & 1 & 2 & 3 & 4 & 5 & 6 & 7 & Strongly Agree \\
\hline
\end{tabular}


If I did not find myself within a walking distance of Boots HS drugstore, it would make it more difficult for me to shop for it.

If I feel embarrassed of shopping for Regaine at Boots HS drugstore, it would make it more difficult for me to purchase it.

$\begin{array}{llllllllll}\text { strongly disagree } & 1 & 2 & 3 & 4 & 5 & 6 & 7 & \text { strongly agree }\end{array}$

If I did not find a good customer service at Boots

HS drugstore, it would make it more difficult for $\quad$ strongly disagree $\quad \begin{array}{llllllll} & 2 & 3 & 4 & 5 & 6 & 7 & \text { strongly agree }\end{array}$ me to shop for Regaine

My family/parents thinks that I should shop for Regaine on Boots using the H.S. drugstore My wife/girlfriend/partner thinks I should for Regaine on Boots using the H.S. drugstore My pharmacist thinks that I should shop for Regaine on Boots using the H.S. drugstore $\begin{array}{llllllllll}\text { strongly disagree } & 1 & 2 & 3 & 4 & 5 & 6 & 7 & \text { Strongly Agree }\end{array}$

Extremely Unlikely $\quad-3 \quad-2-1 \quad 0+1+2+3$ Extremely Likely

$\begin{array}{llllllllll}\text { Extremely Unlikely } & 1 & 2 & 3 & 4 & 5 & 6 & 7 & \text { Extremely Likely }\end{array}$

$\begin{array}{llllllllll}\text { Extremely Unlikely } & 1 & 2 & 3 & 4 & 5 & 6 & 7 & \text { Extremely Likely }\end{array}$ I consider myself to be loyal to Regaine in Boots H.S. Drugstore

Regaine in Boots H.S. Drugstore would be my first choice.

I will not buy other brands if Regaine is available at Boots HS Drugstore

The expected quality of Regaine sold in Boots H.S. drugstore is extremely high.

The likelihood that Regaine purchased in Boots H.S. drugstore would have all its therapeutic properties is very high.

I can recognize Regaine in Boots H.S. drugstore among other competing brands, retailers and channels.

Strongly disagree Strongly disagree

$\begin{array}{lllll}1 & 2 & 3 & 4 & 5\end{array}$ Strongly Agree Strongly disagree

$\begin{array}{lllll}1 & 2 & 3 & 4 & 5\end{array}$ Strongly Agree

Strongly disagree

Strongly disagree

Strongly disagree

Strongly

I am aware of Regaine in Boots H.S. drugstore

If I think about a Package/Bottle of Regaine in Boots H.S drugstore, it comes to my mind quickly.

disagree

Strongly disagree

I can quickly recall the symbol or logo of Regaine.

Strongly disagree

I can quickly recall the symbol or logo of Boots.

I have difficulty in imagining Regaine in Boots H.S. drugstore in my mind.

Strongly disagree

Strongly disagree

It makes sense to buy Regaine in Boots H.S. Drugstore instead of Strongly any other brand-retailer-channel even if they are the same.

Even if another brand-retailer-channel has the same features as Regaine in Boots H.S drugstore, I would prefer to buy Regaine in Boots Drugstore.

If there is another brand-retailer-channel as good as Regaine in Strongly Boots H.S Drugstore, I prefer to buy Regaine in Boots Drugstore.

If another brand-retailer is not different from Regaine in Boots

H.S drugstore in any way, it seems smarter to shop for Regaine in Boots Drugstore. disagree

$\begin{array}{lllll}1 & 2 & 3 & 4 & 5\end{array}$ Strongly Agree

$\begin{array}{lllll}1 & 2 & 3 & 4 & 5\end{array}$ Strongly Agree

$\begin{array}{lllll}1 & 2 & 3 & 4 & 5\end{array}$ Strongly Agree

$\begin{array}{lllll}1 & 2 & 3 & 4 & 5\end{array}$ Strongly Agree

$\begin{array}{lllll}1 & 2 & 3 & 4 & 5\end{array}$ Strongly Agree

$\begin{array}{lllll}1 & 2 & 3 & 4 & 5\end{array}$ Strongly Agree

$\begin{array}{lllll}1 & 2 & 3 & 4 & 5\end{array}$ Strongly Agree

$\begin{array}{lllll}1 & 2 & 3 & 4 & 5\end{array}$ Strongly Agree

$\begin{array}{lllll}1 & 2 & 3 & 4 & 5\end{array}$ Strongly Agree

$\begin{array}{lllll}1 & 2 & 3 & 4 & 5\end{array}$ Strongly Agree

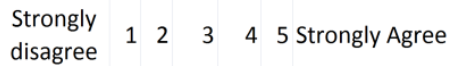

disagree

$\begin{array}{lllll}1 & 2 & 3 & 4 & 5\end{array}$ Strongly Agree

Strongly disagree

$\begin{array}{lllll}1 & 2 & 3 & 4 & 5\end{array}$ Strongly Agree I see myself as:

1. Extroverted, enthusiastic.

$\begin{array}{llllllll}\text { Strongly Disagree } & 1 & 2 & 3 & 4 & 5 & 6 & 7 \text { Strongly Agree }\end{array}$

2. Critical, quarrelsome.

$\begin{array}{lllllllll}\text { Strongly Disagree } & 1 & 2 & 3 & 4 & 5 & 6 & 7 & \text { Strongly Agree }\end{array}$

3. Dependable, self-disciplined.

$\begin{array}{lllllllll}\text { Strongly Disagree } & 1 & 2 & 3 & 4 & 5 & 6 & 7 & \text { Strongly Agree }\end{array}$

4. Anxious, easily upset.

$\begin{array}{lllllllll}\text { Strongly Disagree } & 1 & 2 & 3 & 4 & 5 & 6 & 7 & \text { Strongly Agree }\end{array}$

5. Open to new experiences, complex.

$\begin{array}{lllllllll}\text { Strongly Disagree } & 1 & 2 & 3 & 4 & 5 & 6 & 7 & \text { Strongly Agree }\end{array}$

6. Reserved, quiet.

$\begin{array}{llllllll}\text { Strongly Disagree } & 1 & 2 & 3 & 4 & 5 & 6 & 7\end{array}$ Strongly Agree

7. Sympathetic, warm.

$\begin{array}{llllllll}\text { Strongly Disagree } & 1 & 2 & 3 & 4 & 5 & 6 & 7 \text { Strongly Agree }\end{array}$

8. Disorganized, careless.

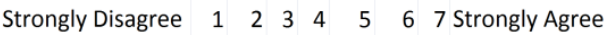



8. Disorganized, careless.
Strongly Disagree $\quad \begin{array}{llllllll}1 & 2 & 3 & 4 & 5 & 6 & 7 \text { Strongly Agree }\end{array}$
9. Calm, emotionally stable.
$\begin{array}{lllllllll}\text { Strongly Disagree } & 1 & 2 & 3 & 4 & 5 & 6 & 7 & \text { Strongly Agree }\end{array}$

10. Conventional, uncreative.

Strongly Disagree $\quad \begin{array}{llllllll}1 & 2 & 3 & 4 & 5 & 6 & 7 \text { Strongly Agree }\end{array}$

Imagine that you are now purchasing Regaine in Boots Drugstore, imagine your mood in there. Now evaluate the following statements according to how you feel in this shopping situation.

\begin{tabular}{|c|c|c|c|c|c|c|c|c|}
\hline I like spending time in the drugstore & Strongly Disagree & 1 & 2 & 3 & 4 & 5 & 6 & 7 Strongly Agree \\
\hline I enjoy exploring around the drugstore & Strongly Disagree & 1 & 2 & 3 & 4 & 5 & 6 & 7 Strongly Agree \\
\hline $\begin{array}{l}\text { I feel friendly to talk to a stranger who happens to } \\
\text { be near me in the drugstore }\end{array}$ & Strongly Disagree & 1 & 2 & 3 & 4 & 5 & 6 & 7 Strongly Agree \\
\hline I feel I want to leave the drugstore quickly & Strongly Disagree & 1 & 2 & 3 & 4 & 5 & 6 & 7 Strongly Agree \\
\hline $\begin{array}{l}\text { I would avoid looking around or exploring other } \\
\text { products in the drugstore }\end{array}$ & Strongly Disagree & 1 & 2 & 3 & 4 & 5 & 6 & 7 Strongly Agree \\
\hline $\begin{array}{l}\text { I would avoid other people or talking to other } \\
\text { people in the drugstore }\end{array}$ & Strongly Disagree & 1 & 2 & 3 & 4 & 5 & 6 & 7 Strongly Agree \\
\hline
\end{tabular}

ABOUT YOURSELF: The following background information questions are included only to help us interpret your responses in relation to other questions. Your responses here and throughout the questionnaire will be held strictly confidential.

\section{1) In what year were you born?}

4) Are you working? Not working Part-time (> $20 \mathrm{hrs} /$ week) $3 / 4$ time ( $20-31 \mathrm{hrs} /$ week) Full time (32-40hrs/week) Self Employed Student Employee Retired Other
3) Highest academic qualification

2) What is your marital status? Married/ living with a partner Widowed Divorced Separated Single/ Never married

6) How many children under $\mathbf{1 8}$ do you have? High school or less Some college Bachelors degree Graduate or professional degree

5) What is your annual household income from all sources before taxes? Less than $£ 9,999$ $£ 10,000-£ 29,999$ $£ 30,000-£ 49,999$ $£ 50,000-£ 69,999$ $£ 70,000-£ 89,999$ $£ 90,000$ and more

7) How is your Household Composed? Living Alone Living with Partner Living with children Living with partner and children Living with parents and eventually

Write your email here to participate in the $100 £$ Amazon voucher raffle: 